\title{
A piaci likviditás és a szabályozás kapcsolatának vizsgálata általános egyensúlyelméleti modellkeretben
}

A pénzügyi válságok következményeként az elmúlt évtizedben középpontba került a szabályozás kérdése. A gyakorlatban szerzett tapasztalat és az elméleti modellek azt mutatják, hogy a likviditási kockázat és a túlzott kockázatvállalás csökkentése érdekében bevezetett szabályozói lépések hatására a piaci szereplők módosítják befektetési döntéseiket, sőt a szabályozói elöírás visszahat a piaci likviditásra. Tranzakciós költséggel (eladási és vételi ár közötti árréssel) bővített általános egyensúlyelméleti modellt alkalmazunk a különböző eszközök likviditása és a bevezetett szabályozói előírás közötti kapcsolat vizsgálatához. A modellben a szabályozás hatására nő az árrés (a piaci likviditás csökkenésének mutatója), ami visszafogja a piaci szereplök közötti kereskedést és kockázatmegosztást. Egyensúlyban a piaci szereplők fogyasztási profilja kockázatosabb marad, alacsonyabb hasznossági szintet érnek el. ${ }^{*}$ Journal of Economic Literature (JEL) kód: G11.

\section{Bevezetés}

A pénzügyi válságok tanulságait felismerve a likviditási kockázat mérséklése a szabályozás kulcskérdése lett. Ugyanakkor a magasabb tőkekövetelmény, a likvid eszközállomány elöírása, illetve az alacsonyabb kockázatvállalás ösztönzése visszahat a piaci likviditásra. A tanulmány egy olyan keretrendszert definiál, amely segítségével elemezhető a szabályozás és a piaci likviditást megragadó árrés kapcsolata.

A tranzakciós költséggel (eladási és vételi ár közötti árréssel) bővített általános egyensúlyelméleti modellben a piaci szereplők kereskedésének célja, hogy a jövőbeli világállapottól függő kifizetésüket és (ezzel fogyasztásukat) simítsák a kockázatok megosztásán keresztül. A felírt keretrendszer számos gyakorlati probléma leírására

* A tanulmány az Innovációs és Technológiai Minisztérium ÚNKP-19-3-IV kódszámú Új Nemzeti Kiválóság Programjának szakmai támogatásával készült. Köszönöm témavezetőm, Csóka Péter szakmai iránymutatását és tanácsait. Emellett szeretném megköszönni Carlo Acerbi, Zawadowski Ádám és Neszveda Gábor előremutató megjegyzéseit.

Hevér Judit, Budapesti Corvinus Egyetem Befektetések és Vállalati Pénzügy Tanszék. A kézirat első változata 2020. március 1-jén érkezett szerkesztőségünkbe.

DOI: http://dx.doi.org/10.18414/KSZ.2020.7-8.708 
alkalmas, hiszen a kezdeti és jövőbeli sztochasztikus készletek határozzák meg az adott piaci szereplő viselkedését és gazdaságban betöltött szerepét. Ha a jelenben a piaci szereplő jelentős pozitív készlettel rendelkezik, akkor optimumban készletének nagy részét tőketulajdonosként befektetheti. Ha a jövőben pozitív készlet realizálására számít, a jelenben viszont nem rendelkezik elegendő jövedelemmel és tőkével, akkor hitelfelvevő háztartásként/vállalatként viselkedik. Míg ha a jövőbeli világállapotok egy részében pozitív, egy részében negatív készletet realizál, akkor az eszközök tartásával fedezheti kockázatos pozícióját.

A modellben a legrosszabb kimenetekben várható negatív kifizetés függvényében meghatározott szabályozói elöírás a piaci szereplök kockázatvállalásának csökkentése érdekében történik. Az előírás visszafogja a hitelfelvevő háztartások túlzott eladósodását, mérsékli a tőketulajdonosok kockázatvállalását a befektetési döntések meghozatalánál, emellett biztosítja a kockázatos jövőbeli pozíciókon elszenvedett veszteség kifizetését és a likvid eszközök tartását. A szabályozó a különböző eszközök tartása esetén eltérő szabályozási paramétert alkalmazhat, amellyel a preferált eszközök kereslete növelhető a kerülendő eszközök keresletének rovására. Például ha a szabályozó a környezeti, társadalmi és vállalatirányítási (Environmental, Social, and Governance, ESG) kockázat alapján határozza meg a paramétert, modellezhetjük a fenntartható eszközök tartásának ösztönzésére irányuló szabályozói lépést.

A piaci likviditást a tanulmányban az árrés, azaz a vételi és az eladási árak közötti különbség nagyságával mérjük. A modellben a piaci szereplök nem tudnak közvetlenül kereskedni, árjegyző párosítja az ellenoldali ajánlatokat, és monopolistaként határozza meg a számára optimális endogén árrést. Minden árrés mellett meghatározza a piaci szereplők legjobb válaszát, majd kiválasztja a számára legmagasabb profitot biztosító esetet. Mivel a szabályozói elöírás bevezetése plusz korlátozó feltétellel módosítja a piaci szereplők optimalizálási döntését, a korábban optimális portfólió nem biztos, hogy elérhető marad, így az elérhető hasznosság adott árrés mellett nem nőhet. Ha a piaci szereplő az optimális döntés során beleütközik a szabályozói elöírásba, akkor az árjegyzönek megéri növelni az árrést arra a szintre, amelynél a szabályozói elöírás mellett keresett portfólió a piaci szereplő legjobb válasza. Azaz a szabályozói előírás bevezetése (ha az optimalizáló szereplö beleütközik a korlátozó feltételbe) csökkenti a piaci likviditást és a piaci szereplök hasznosságát.

Természetesen a gyakorlatban a szabályozás kérdése sokkal összetettebb, és a piaci tökéletlenségek indokolják a beavatkozást. A tanulmány ugyanakkor megerősíti, hogy a beavatkozás költségekkel jár, a szabályozási előírás bevezetése viszszahat a piaci likviditásra. A szabályozási mechanizmusok tervezésekor ezt a szempontot is mérlegelni kell.

A tanulmányban elöször a szabályozási gyakorlatot és a kapcsolódó irodalmat foglaljuk össze, majd a jelölések ismertetése után vázoljuk az általános egyensúlyelméleti keretet, amely leírja a piaci szereplők fogyasztási és portfólióallokálási döntését - szabályozói lépések bevezetése mellett is -, vázolja az árjegyző döntési problémáját, és megadja a piaci egyensúly feltételeit. Az ezt követő rész bemutatja a kétszereplös modellt, és példák segítségével illusztrálja az eredményeket. Végül a megállapítások összefoglalásával zárjuk a tanulmányt. 


\section{Szabályozási gyakorlat és a kapcsolódó irodalom}

Az elmúlt évtizedek likviditási válságai, a fekete hétfő 1987-ben, az Egyesült Államok és Irak közötti háború 1990-ben, az LTCM összeomlása 1998-ban vagy a 2007-es amerikai jelzáloghitel-válság bizonyítják a likviditás pénzügyi piacokon betöltött kulcsszerepét (Brunnermeier-Pedersen [2008]). Számos tanulmány elemzi a válságok eredetét és dinamikáját. Brunnermeier-Pedersen [2008] a piaci likviditás (market liquidity) és a finanszírozási likviditás (funding liquidity) kétirányú interakcióját és likviditási válságok kialakulásában játszott szerepét modellezi. Amihud és szerzötársai [1990] a tőzsdék összeomlása és a likviditási válság közötti kapcsolatot vizsgálta az 1987-es csődhullám példáján keresztül, és kitért arra, hogy a központi bankok és a szabályozó szervek milyen lépésekkel reagálhatnak egy likviditási sokkra. Mitchell és szerzőtársai [2007] az átváltható kötvények piacának 2005. évi összeomlását elemezte, és arra a következtetésre jutott, hogy a tőke szűkössége miatt likviditási válság esetén a piacok lassan állnak helyre, azaz az arbitrázs hosszú ideig fennmaradhat.

A kialakult válságok és a válságokat elemző tanulmányok felhívták a szabályozó szervek figyelmét a likviditás vizsgálatának fontosságára, miközben a pénzügyek számos területén középpontba került a szabályozás kérdése. 2013 januárjában a Bázeli Bizottság (Basel Committee on Banking Supervision, BCBS) a bankokra vonatkozó Bázel-III. szabályozás elemeként két új likviditási mértéket, a likviditásfedezeti mutatót (Liquidity Coverage Ratio, $L C R)^{1}$ és a nettó stabil forrás mutatót (Net Stable Funding Ratio, NSFR) ${ }^{2}$ vezette be ( $B C B S$ [2013]). A bankrendszer sokktürö képességét növelö szabályozás elöírja, hogy a bankok kötelesek elegendő mennyiségü, a pénzpiacon könnyen és azonnal likvidálható eszközt tartani, illetve a kitettségeiket stabil forrással fedezni.

A bankrendszer szabályozásával párhuzamosan folyamatosan megújulnak az IOSC (International Organisation of Securities Commissions) pénzügyi alapok kezelésével kapcsolatos ajánlásai. Az IOSC [2018] ajánlás célja, hogy javítsa a nyílt végü befektetési alapok likviditási kockázatának kezelését azért, hogy védje a befektetőket, javuljon a pénzügyi piacok hatékonysága, és csökkenjen a szisztematikus kockázat. Érdekes szabályozási irány az IOSC [2019b] jelentésben megfogalmazott fenntartható pénzügyek (sustainable finance) irányába történő elmozdulás ösztönzése. A tanulmány a fejlődő piacok szemszögéből közelíti meg a kérdést, és 11 javaslatot fogalmaz meg, amelyeket a szabályozó szerveknek célszerü figyelembe venni a fenntartható eszközök és az ESG-típusú specifikus kockázatok szabályozásakor. Az ESG-szempontok befektetésekre gyakorolt hatását Naffa-Fain [2019] vizsgálta.

A SEC (U.S. Securities and Exchange Commissions) célkitűzései között fontos szerepet kap a pénzügyi piacokon befektető vagy hitelfelvevő háztartások védelme. ${ }^{3}$

\footnotetext{
${ }^{1}$ A likviditásfedezeti mutató előírt értéke 2019 januárjától 100 százalék, azaz a bankok legalább annyi likvid eszközt kötelesek tartani, mint amennyi a nettó kumulált pénzkiáramlás a következő 30 napban.

${ }^{2}$ Láng [2017] alapján az NSFR az elérhető stabil forrás (available stable funding, ASF) és a szükséges stabil forrás (required stable funding, RSF) hányadosa, amelynek el kell érnie a 100 százalékot.

${ }^{3}$ "The SEC enforces the securities laws to protect the more than 66 million American households that have turned to the securities markets to invest in their futures - whether it's starting a family, sending kids to college, saving for retirement or attaining other financial goals." (https://www.sec.gov/.)
} 
Ugyanakkor a pénzügyi intézményi oldal szabályozása mellett a háztartások pénzügyi kultúrájának fejlesztése, a túlzott kockázatvállalás és eladósodottság visszaszorítása is kulcsfontosságú. Király és szerzőtársai [2008] szerint a 2007-es amerikai jelzáloghitel-válság kirobbanásának fontos előzménye a fejlett országok esetében kialakuló fogyasztási többlet és ezzel párhuzamosan a hitelboomok kialakulása és a háztartások tökeáttételének növekedése. A probléma megoldását nehezíti, hogy a pénzügyi tanácsadók javaslatait a háztartások csupán elenyésző hányada fogadja meg, még abban az esetben is, amikor a tanácsadók önérdeke az értékesítéstől teljesen független, azaz félrevezetéstöl nem kell tartaniuk (Stolper [2018]). Stolper [2018] és Brounen és szerzőtársai [2016] megállapította, hogy a pénzügyi müveltség szignifikánsan emeli a tanácsadás követésének és a megtakarításnak a valószínűségét. Campbell [2016] olyan modellkeretben vizsgálta a háztartások pénzügyi és fogyasztási döntéseinek szabályozását, amelyben a háztartások jelentős hányada nem rendelkezik az öngondoskodáshoz szükséges ismeretanyaggal. Eredménye a beavatkozás szükségességét hangsúlyozza.

A szabályozási gyakorlat mellett elméleti modellek is bevezetnek korlátozó feltételeket a szereplők döntési problémájába. Acerbi-Scandolo [2008] likviditási követelmény melletti portfólióértéket definiált, amely a portfóliók legjobb vételi és eladási árakon történő értékelése helyett figyelembe veszi, hogy a jövőbeli tervek megvalósítása az eszközök egy részének likvidálását követeli meg. Bigio [2015] modelljében a vállalatok az eszközök azonnali likvidálásának problémájával szembesülnek, illetve - a szerződések korlátozott kikényszeríthetőségéből következő bizonytalanság miatt - a fedezettartás szükségességével. Kiyotaki-Moore [2019] korlátozta a vállalkozók hitelfelvételét, így a befektetéshez likvidálni kell illikvid eszközeik egy részét. Csóka [2017] egy eladósodott vállalat divíziói közötti kockázatmegosztás lehetőségét pénzügyi korlátok mellett modellezte. Gromb-Vayanos [2010] a pénzügyi közvetítők tőkéje és a piaci likviditás közötti összefüggést modellezte. A modellben az alacsony likviditás miatt jelentkező arbitrázs teljes kihasználását és a piaci likviditás biztosítását akadályozzák a szofisztikált befektetők pénzügyi korlátai.

Számos tanulmány vizsgálta a szabályozási előírások sikerességét és lehetséges költségeit. De Nicolò és szerzőtársai [2014] részpiaci egyensúlyi modell keretében megmutatta, hogy a Bázel-III. keretében bevezetett likviditásfedezeti mutató alkalmazása visszafogja a hitelezést, csökken a hatékonyság és a jólét szintje. Begenau [2019] dinamikus általános egyensúlyelméleti modell segítségével vizsgálta a tökekövetelmény optimális szintjét. A bevezetett tőkekövetelmény a betétek szükösségén keresztül csökkenti a bankok tőkeköltségét, és növeli a bank hitelezési tevékenységét, mi több, a magasabb tőkekövetelmény ösztönzi a bankok monitoringtevékenységét, ezzel növelve a banki tevékenységek hatékonyságát. Ezzel szemben az IOSC [2019a] jelentés hangsúlyozta, hogy a vállalati kötvények másodpiacának válság utáni szabályozása korlátozza a pénzügyi közvetítőket a likviditás biztosításában, így a stressztesztek alapján a piaci nyomás a korábbiaknál súlyosabb hozamelmozdulást eredményezhet. Sommer-Sullivan [2018] modellje szerint a jelzáloghitelek adókedvezményének eltörlése az ingatlanárak és a jelzáloghitel-állomány csökkenését és a jólét emelkedését eredményezné. 
Módszertanunkhoz hasonlóan általános egyensúlyelméleti keretet használt LeRoyWerner [2001], Csóka és szerzötársai [2007], Herings-Zhou [2019], Eisfeldt [2004], Köhegyi-Stépán [2003] és Zalai [1998]. Ezek a tanulmányok a felírt modell megoldásához nyújtanak segítséget.

\section{Az általános egyensúlyelméleti modell}

A tanulmány az általános egyensúlyelméleti modell felépítésében alapvetőn LeRoyWerner [2001] könyvére támaszkodik. Újítás ugyanakkor a várható veszteség függvényeként bevezetett szabályozói előírás, az árjegyző endogén árrésének használata és a készpénz kiemelése az eszközök közül, ami akár minden szereplő számára egyszerre is lehetővé teszi a kockázatmentes eszközben történő megtakarítást.

\section{Jelölésrendszer}

A jelölések bevezetése Csóka-Herings [2014] és LeRoy-Werner [2001] alapján történik. Két időszakos modellt feltételezünk: a kockázatos eszközökkel a 0 -adik időszakban kereskednek, míg a kifizetések az első időszakban történnek. Egy piaci szereplő kockázatmentes eszközt/készpénzt és $J$ különböző kockázatos eszközt tarthat. Tegyük fel, hogy a kockázatmentes eszköz kamatlába 0 százalék a piacon. Az első időszakban $S$ különböző világállapot realizálódhat, amelyek közül $s \in\{1, \ldots, S\}$ világállapot $\pi_{s}>0$ valószínüséggel következik be, és $\sum_{s=1}^{s} \pi_{s}=1$. Jelölje $x_{j s} \in \mathbb{R}$ a $j$-edik $(j \in J)$ eszköz kifizetését az $s$-edik $-s \in\{1, \ldots, S\}$ - világállapotban. Míg $x_{j}=\left[x_{j 1}, \ldots, x_{j \mathrm{~s}}\right] \in \mathbb{R}^{\mathbb{S}}$ vektor a $j$-edik $(j \in J)$ eszköz kifizetését az összes világállapotban és $X \in \mathbb{R}^{J} \times \mathbb{R}^{S}$ mátrix az összes eszköz kifizetését tartalmazó kifizetésmátrixot jelöli. ${ }^{4}$

A tanulmányban feltételezzük, hogy az árjegyző meghatározza a vételi és eladási ár közötti, számára optimális árrést. Jelölje a j-edik eszközre vonatkozó árrést $t_{j}=a_{j}-b_{j}$, ahol $a_{j}$ az eladási (ask), $b_{j}$ pedig a vételi (bid) ár. A $b \in \mathbb{R}^{J}$ árvektor (oszlopvektor) a vételi árakat jelöli, azaz megmutatja $\forall j \in J$-re azt a $b_{j}$ árat, amelyen a $j$-edik eszköz likvidálható. Az $a \in \mathbb{R}^{J}$ oszlopvektor az eladási (ask) árakat tartalmazza, $\forall j \in J$-re azt az $a_{j}$ árat, amelyért meg tudjuk venni a $j$-edik eszköz egy egységét. Jelölje $t \in \mathbb{R}^{I}$ a $t_{j}$ árrések oszlopvektorát. Ha a piacon nincs arbitrázs, ${ }^{5}$ akkor $a_{j} \geq b_{j} \forall j \in J$ esetén, azaz $t_{j} \geq 0$.

Egy kockázatos portfólió $J$ eszközből áll. Jelölje $\times=\mathbb{R}^{J}$ a portfóliók terét, $\theta \in \times$ pedig egy portfóliót/pozíciót. A befektető piaci szereplők halmaza $I$. A $\theta^{i} \in \mathbb{R}^{I}$ portfólió megmutatja, hogy az $i \in I$ befektető milyen eszközöket tart és adott el rövidre. LeRoy-Werner [2001] alapján a szereplök két portfóliót választanak, $\theta_{b}^{i} \geq 0$-t adják el a vételi árakon, és $\theta_{a}^{i} \geq 0$-t veszik az eladási árakon, azaz $\theta^{i}=\theta_{a}^{i}-\theta_{b}^{i}$ pozíciót tartanak. Az $i$-edik szereplö $c_{0}^{i}$-t fogyaszt a 0 -adik időszakban és $c_{1}^{i}=\left[c_{11}^{i}, \ldots, c_{1 S}^{i}\right]$-t az 1 . időszakban, ahol $c_{1 s}$ az $s \in\{1, \ldots, S\}$ világállapotban választott fogyasztási szintet jelöli.

\footnotetext{
${ }^{4} \mathrm{Ha}$ az $X$ mátrix rangja $S$, akkor a piac teljes. A tanulmányban nem feltételezünk teljes piacot.

${ }^{5}$ Nincs arbitrázs, ha $\nexists$ olyan $\theta_{a} \geq 0$ és $\theta_{b} \geq 0$ portfóliók, amelyekre $\theta_{a}^{i} a-\theta_{b}^{i} b<0$ és $\left(\theta_{a}^{i}-\theta_{b}^{i}\right) X \geq 0$.
} 
Az $i$-edik szereplő rendelkezésére álló készpénz készlete a 0 -adik időszakban $\omega_{0}^{i}$, az 1. időszakban pedig a világállapottól függő valószínűségi változó, $\omega_{1}^{i}=\left[\omega_{11}^{i}, \ldots, \omega_{1 S}^{i}\right]$. A tanulmányban az $i$-edik szereplö preferenciáit a folytonos $u^{i}: \mathbb{R}^{S+1} \rightarrow \mathbb{R}$ hasznossági függvénnyel írjuk le.

\section{A piaci szereplők fogyasztási és portfólióallokálási döntése}

A piaci szereplők fogyasztási és portfólióallokálási döntését első lépésként szabályozás beavatkozása nélkül, majd a várható veszteség függvényében megadott szabályozói elöírás mellett mutatjuk be.

Az OPTIMALIZÁLÁSI PROBLÉMA SZABÁLYOZÓI ELŐÍRÁS NÉLKÜL • Az i-edik befektető optimális fogyasztási és portfólióallokálási döntése a következő optimalizálási feladat megoldásaként adható meg:

$\max _{c_{0}^{i}, c_{1}^{i}, \theta_{a}^{i}, \theta_{b}^{i}, \theta_{0}^{i}} u^{i}\left(c_{0}^{i}, c_{1}^{i}\right)$,

feltéve, hogy

$c_{0}^{i} \leq \omega_{0}^{i}-\theta_{a}^{i} a+\theta_{b}^{i} b-\theta_{0}^{i}$

$c_{1}^{i} \leq \omega_{1}^{i}+\left(\theta_{a}^{i}-\theta_{b}^{i}\right) X+\theta_{0}^{i} 1^{s}$

$\theta_{a}^{i} \geq 0$

$\theta_{b}^{i} \geq 0$.

A szereplők hasznosságuk maximalizálásakor a $c_{0}^{i}$ és $c_{1}^{i}$ fogyasztásról, a 0. időszakban megvásárolt, 1 . időszakban kifizetést biztosító $\theta^{i}=\theta_{a}^{i}-\theta_{b}^{i}$ portfólióról és a $\theta_{0}^{i}$ félretett készpénzmennyiségről döntenek. A döntést korlátozza, hogy a 0. időszaki $c_{0}^{i}$ fogyasztás nem haladhatja meg azt az összeget, amely az $\omega_{0}^{i}$ kezdeti készletből a $\theta^{i}$ portfólió nyitása és $\theta_{0}^{i}$ kockázatmentes eszköz (készpénz vagy bankbetét) tartása után marad. Míg az első időszaki $c_{1}^{i}$ sztochasztikus fogyasztás nem nagyobb, mint az $\omega_{1}^{i}$ sztochasztikus készlet, a $\theta^{i}$ portfólió kifizetése és a $\theta_{0}^{i}$ félretett kockázatmentes eszköz összege.

SZABÁLYOZÓI ELÖÍRÁS A VÁRHATÓ VESZTESÉG FÜGGVÉNY EKÉNT • Vizsgáljuk aZtaZ esetet, amikor a piaci szereplőknek a portfólió várható veszteségének (Expected Shortfall, $E S)$ függvényeként megadott szabályozói elöírásnak kell megfelelniük! Az ES definiálásához a Csóka és szerzőtársai [2009] tanulmányt követjük. A j-edik $(j \in J)$ eszköz esetén jelölje az $x_{j 1}, \ldots, x_{j s}$ kimenetek rendezett értékeit $x_{j, s: S}$, ahol $\left\{x_{j, 1: S}, \ldots, x_{j, s: S}\right\}=\left\{x_{j 1}, \ldots, x_{j s}\right\}$ és $x_{j, 1: s} \leq x_{j, 2: s} \ldots \leq x_{j, s: s^{*}}$ A különböző világállapotok bekövetkezésének a valószínüsége megegyezik, azaz tegyük fel, hogy $\pi_{1}=\ldots=\pi_{s}=1 / \mathrm{S}$. 
1. DEFINíció • A kimenetek bekövetkezésének valószínüsége azonos, és $k \in\{1, \ldots, S\}$. $A$ j-edik $(j \in J)$ eszköz esetén a kimenetek $x_{j}$ realizációs vektorára a $k$-várható veszteség $\left(E S_{k}\right) a z$

$E S_{k}\left(x_{j}\right)=-\sum_{s=1}^{k} \frac{1}{k} x_{j, s: S}$

egyenlettel definiálható.

Ha a várható kifizetés a $k$ legalacsonyabb kifizetést biztosító világállapotban negatív, azaz veszteségröl beszélhetünk, akkor az ES értéke pozitív lesz. Míg várható nyereség esetén az ES értéke negatív. Tegyük fel, hogy a szabályozó minden $j$-edik $(j \in J)$ eszköz esetében meghatároz egy $\delta_{j}$ szabályozói paramétert, amely eszközönként/ piaconként különbözhet. A j-edik $(j \in J)$ eszközre a tökekövetelmény a $\theta_{j}^{i}=\theta_{a j}^{i}-\theta_{b j}^{i}$ pozíció kimeneteire számszerüsített $E S \delta_{j}$-szerese lesz. A tőkeallokálásra vonatkozó szabály szerint a piaci szereplők annyi kockázatmentes eszközt kötelesek tartani, amennyi meghaladja a $\theta^{i}=\theta_{a}^{i}-\theta_{b}^{i}$ portfólió azon $j$-edik $(j \in J)$ eszközeire összegzett tőkekövetelmény nagyságát, amelyek $E S$-értéke pozitív. Ebben az esetben az $i$-edik befektető optimális fogyasztási és portfólióallokálási döntése a következő optimalizálási feladat megoldásaként adható meg:

$\max _{c_{0}^{i}, c_{1}^{i}, \theta_{a}^{i}, \theta_{b}^{i}, \theta_{0}^{i}} u^{i}\left(c_{0}^{i}, c_{1}^{i}\right)$,

feltéve, hogy

$c_{0}^{i} \leq \omega_{0}^{i}-\theta_{a}^{i} a+\theta_{b}^{i} b-\theta_{0}^{i}$

$\theta_{0}^{i} \geq \sum_{j \in J} \delta_{j} \max \left[0, E S_{k}\left(\theta_{j}^{i} x_{j}\right)\right]$

$c_{1}^{i} \leq \omega_{1}^{i}+\left(\theta_{a}^{i}-\theta_{b}^{i}\right) X+\theta_{0}^{i} 1^{s}$

$\theta_{a}^{i} \geq 0$

$\theta_{b}^{i} \geq 0$.

Az árjegyző döntési problémája

A modellben a piaci szereplök nem kereskedhetnek közvetlenül, árjegyzö/közvetítő párosítja az ellenkező oldali ajánlatokat, és elfogyasztja a profitját a 0 . időszakban. Egyensúlyban az árjegyző a modellben csak közvetítőként jelenik meg, nem tart eszközöket, így nem szükséges a veszteség fedezését biztosító tőkét félretennie. A pénzügyi piacok mikrostruktúráját és azon belül az árjegyzői piacokat Erb-Havran [2015] részletesen bemutatja. Tanulmányukban kiemelik, hogy a piaci tökéletlenségek hátterében a cserepartner-keresés és a kapcsolatteremtés költsége, hálózati externáliák, aszimmetrikus információ és a készlettartás költsége egyaránt állhat, amely okok különböző piaci mikrostruktúrák kialakulásához vezetnek. 
Jelen tanulmányban LeRoy-Werner [2001] alapján a legegyszerübb esetet feltételezzük, az árjegyzö/közvetítő tranzakciós monopolistaként dönt minden eszköz esetén az eladási és vételi ár különbségéről, azaz az árrésről, ezzel befolyásolva a különböző eszközök piacának likviditását. Havran-Szücs [2016] a közvetítői hálózatok elemzésekor duopolista árjegyzői magatartást feltételezett, amely egy további kutatási irányként jelen modellkeretben szintén vizsgálható lenne.

Definiáljuk a j-edik $(j \in J)$ eszközre a $T_{j}\left(\theta_{j}^{1}, \ldots, \theta_{j}^{I}\right)$ tranzakciós költségfüggvényt $T_{j}\left(\theta_{j}^{1}, \ldots, \theta_{j}^{I}\right)=t_{j} \sum_{i \in I} \theta_{a j}^{i}=t_{j} \sum_{i \in I} \theta_{b j}^{i}$

alakban. Az árjegyző profitot maximalizál, így optimalizálási feladatában

$$
\max _{t_{j} \forall j \in J} \sum_{j \in J} T_{j}\left(\theta_{j}^{1}, \ldots, \theta_{j}^{I}\right)=\sum_{j \in J} t_{j} \sum_{i \in I} \theta_{a j}^{i},
$$

feltéve, hogy a befektető piaci szereplők hasznosságot maximalizálva döntenek a $\theta_{a}^{i}$ és $\theta_{b}^{i}$ portfóliókról.

1. LEMMA • Ha az árjegyzö a (4) optimalizálási feladat szerint optimalizál, akkor $t_{j}$ $\forall j \in J$ eszközre nemnegatív.

BizonYíTÁs $\bullet$ Tegyükfel, hogy $\exists \hat{j} \in J$, amelyre $t_{\hat{j}}<0$. Ekkor a $\hat{j}$ eszköz esetén bármely $\theta_{a \hat{j}}^{i}=\theta_{b \hat{j}}^{i}>0$ pozíció arbitrázs a piacon, hiszen a 0 . időszakban a $-\theta_{a j}^{i} a_{\hat{j}}+\theta_{b \hat{j}}^{i} b_{\hat{j}}>0$, míg az 1 . időszakban a kifizetés $\left(\theta_{a j}^{i}-\theta_{b \hat{j}}^{i}\right)=0$. Mivel a kifizetés minden $s \in\{1, \ldots, S\}$ világállapotban 0 , és a várható veszteség $(E S)$ is 0 , ezért a piaci szereplők ki tudják használni az arbitrázst a korábbiakban az (1) és a (2) összefüggéssel leírt modell esetében is, ami veszteséget okoz az árjegyzőnek. Így nem lehetett optimális döntése a $t_{\hat{j}}<0$ árrés.

\section{A piactisztító feltételek egyensúlyban}

Egy egyensúly megadható a piaci szereplők optimális kockázatoseszköz-portfóliói, az optimális készpénzmennyiség, az optimális fogyasztási szintek és az optimális árrések halmazaként $\left\{\theta_{a j}^{* i}, \theta_{b j}^{* i}, \theta_{0}^{* i}, c_{0}^{* i}, c_{1}^{* i}, t_{j}^{*}\right\}$ alakban, ahol $\theta_{a j}^{* i}, \theta_{b j}^{* i}, \theta_{0}^{* i}, c_{0}^{* i}$ és $c_{1}^{* i}$ megoldása a piaci szereplők optimalizálási feladatának, míg $t_{j}^{*}$ az árjegyző optimalizálási problémájának megoldása. A piactisztító feltétel a tőkepiacon és a fogyasztási piacon a 0 . és az 1. időszakban a következő:

$$
\begin{aligned}
& \sum_{i \in I} \theta^{i}=\sum_{i \in I}\left(\theta_{a}^{i}-\theta_{b}^{i}\right)=0 \\
& \sum_{i \in I} c_{0}^{i} \leq \sum_{i \in I} \omega_{0}^{i}-\sum_{j \in J} T_{j}\left(\theta_{j}^{1}, \ldots, \theta_{j}^{I}\right)-\sum_{i \in I} \theta_{0}^{i} \\
& \sum_{i \in I} c_{1}^{i} \leq \sum_{i \in I} \omega_{1}^{i}+\sum_{i \in I} \theta_{0}^{i} 1^{S} .
\end{aligned}
$$


1. ÁLLÍTÁs • Egyensúlyban, ha a tőkepiac egyensúlyban van,

$\sum_{i \in I} \theta^{i}=\sum_{i \in I}\left(\theta_{a}^{i}-\theta_{b}^{i}\right)=0$,

akkor a fogyasztási piac is egyensúlyban lesz,

$$
\begin{aligned}
& \sum_{i \in I} c_{0}^{i} \leq \sum_{i \in I} \omega_{0}^{i}-\sum_{j \in J} T_{j}\left(\theta_{j}^{1}, \ldots, \theta_{j}^{I}\right)-\sum_{i \in I} \theta_{0}^{i} \\
& \sum_{i \in I} c_{1}^{i} \leq \sum_{i \in I} \omega_{1}^{i}+\sum_{i \in I} \theta_{0}^{i} 1^{S} .
\end{aligned}
$$

Bızonyítás • Összegezzük az összes $i$-edik $(i \in I)$ piaci szereplő 0 . és 1. időszaki költségvetési korlátját:

$$
\begin{aligned}
& \sum_{i \in I} c_{0}^{i} \leq \sum_{i \in I} \omega_{0}^{i}-\sum_{i \in I} \theta_{a}^{i} a+\sum_{i \in I} \theta_{b}^{i} b-\sum_{i \in I} \theta_{0}^{i} \\
& \sum_{i \in I} c_{1}^{i} \leq \sum_{i \in I} \omega_{1}^{i}+\sum_{i \in I}\left(\theta_{a}^{i}-\theta_{b}^{i}\right) X+\sum_{i \in I} \theta_{0}^{i} 1^{S} .
\end{aligned}
$$

Tökepiaci egyensúlyban

$\sum_{i \in I} \theta_{a}^{i}=\sum_{i \in I} \theta_{b}^{i}$

ezért

$$
\begin{aligned}
& \sum_{i \in I} \theta_{a}^{i} a-\sum_{i \in I} \theta_{b}^{i} b=\sum_{i \in I} \theta_{a}^{i}(a-b)=\sum_{i \in I} \theta_{a}^{i} t=\sum_{i \in I} \sum_{j \in J} \theta_{a j}^{i} t_{j}= \\
& =\sum_{j \in J} t_{j} \sum_{i \in I} \theta_{a j}^{i}=\sum_{j \in J} T_{j}\left(\theta_{j}^{1}, \ldots, \theta_{j}^{I}\right),
\end{aligned}
$$

és

$$
\sum_{i \in I}\left(\theta_{a}^{i}-\theta_{b}^{i}\right) X=\left(\sum_{i \in I} \theta_{a}^{i}-\sum_{i \in I} \theta_{b}^{i}\right) X=0 .
$$

2. ÁLlítÁs. Tegyük fel, hogy az i-edik szereplö preferenciáit leíró $u^{i}: \mathbb{R}^{S+1} \rightarrow \mathbb{R}$ hasznossági függvény folytonos és szigorúan monoton. Ekkor a költségvetési korlátok egyenlöséggel teljesülnek, és a fogyasztási piaci egyensúlyból következik a tökepiaci egyensúly. ${ }^{6}$

3. ÁllítÁs. Tegyük fel, hogy az i-edik szereplő preferenciáit leíró $u^{i}: \mathbb{R}^{S+1} \rightarrow \mathbb{R}$ hasznossági függvény folytonos és szigorúan monoton. Ekkor egyensúlyban $\forall j \in J$ eszközre és $\forall i \in I$ piaci szereplö esetén létezik olyan optimális portfólió, amelyre

$\theta_{a j}^{i} \theta_{b j}^{i}=0$.

\footnotetext{
${ }^{6} \mathrm{Az}$ állítást bizonyítás nélkül közöljük, mivel nem hivatkozunk rá a tanulmányban.
} 
Bizonyítás. Az 1. LEMma alapján egyensúlyban $\forall j \in J$ eszközre a $t_{j} \geq 0$. Tegyük fel, hogy $\exists \hat{i} \in I$ szereplő, akinek az optimális pozíciójában $\exists \hat{j} \in J$ eszköz, amelyre $\theta_{a \hat{j}}^{\hat{i}} \theta_{b \hat{j}}^{\hat{i}} \neq 0$. A szigorúan monoton hasznossági függvény miatt a költségvetési korlát egyensúlyban egyenlőséggel teljesül:

$c_{0}^{\hat{i}}=\omega_{0}^{\hat{i}}-\theta_{a}^{\hat{i}} a+\theta_{b}^{\hat{i}} b-\theta_{0}^{\hat{i}}$.

Definiáljunk egy új $\bar{\theta}_{a}^{\hat{i}}$ portfóliót úgy, hogy $\bar{\theta}_{a j}^{\hat{i}}=\theta_{a j}^{\hat{i}} \forall j \in J, j \neq \hat{j}$ esetén, és $\bar{\theta}_{a \hat{j}}^{\hat{i}}=\theta_{a \hat{j}}^{\hat{i}}-\theta_{b j}^{\hat{i}}$. Míg az új $\bar{\theta}_{b}^{\hat{i}}$ portfólió $\bar{\theta}_{b j}^{\hat{i}}=\theta_{b j}^{\hat{i}} \forall j \in J, j \neq \hat{j}$ esetén, és $\bar{\theta}_{b \hat{j}}^{\hat{i}}=0$. Mivel

$\theta_{a}^{\hat{i}}-\theta_{b}^{\hat{i}}=\bar{\theta}_{a}^{\hat{i}}-\bar{\theta}_{b}^{\hat{i}}$,

ezért az új $\theta^{\hat{i}}$ pozíció kifizetése az 1 . időszakban megegyezik a $\theta^{\hat{i}}$ pozíció kifizetésével.

Ugyanakkor, ha a $t_{\hat{j}}$ árrés pozitív, akkor az elérhető új fogyasztási szint a 0 . időszakban:

$\overline{c_{0}^{\hat{i}}}=\omega_{0}^{\hat{i}}-\overline{\theta_{a}^{\hat{i}}} a+\overline{\theta_{b}^{\hat{i}}} b-\theta_{0}^{\hat{i}}>c_{0}^{\hat{i}}=\omega_{0}^{\hat{i}}-\theta_{a}^{\hat{i}} a+\theta_{b}^{\hat{i}} b-\theta_{0}^{\hat{i}}$.

Így a hasznossági függvények szigorú monotonitása miatt a $\theta^{\hat{i}}$ pozíció nem lehetett az $\hat{i}$ szereplő optimális döntése. Ha pedig a $t_{\hat{j}}$ árrés 0 , akkor a $\theta^{\hat{i}}$ portfólióhoz hasonlóan a $\theta^{\hat{i}}$ portfólió is optimális.

Egyensúly szabályozói elöírás bevezetésével és a nélkül

A tanulmány kulcskérdése, hogy mi történik a piaci likviditással a szabályozói előírás bevezetésekor. A kérdés vizsgálatához össze kell hasonlítanunk azt az egyensúlyt, amelynek meghatározásakor a piaci szereplők a szabályozói előírás bevezetése nélkül az (1) optimalizálási probléma alapján döntenek, azzal az egyensúllyal, a melyet a szabályozói korlát teljesítését is előíró (2) optimalizálási feladat megoldása határoz meg. A szabályozói előírás bevezetésével a feltételes szélsőérték-feladat megoldása addicionális korlát mellett történik, ezért a döntési lehetőségek halmaza nem bővülhet. Két esetet különböztethetünk meg.

4. ÁllítÁs • Legyen a $\left\{\theta_{a j}^{* i}, \theta_{b j}^{* i}, \theta_{0}^{* i}, c_{0}^{* i}, c_{1}^{* i}, t_{j}^{*}\right\}$ egyensúly, ahol $\theta_{a j}^{* i}, \theta_{b j}^{* i}, \theta_{0}^{* i}, c_{0}^{* i}$ és $c_{1}^{* i}$ megoldása a piaci szereplők (1) optimalizálási feladatának. Ha $\forall i \in I$-re $\theta_{0}^{* i} \geq \sum_{j \in J} \delta_{j} \max \left[0, E S_{k}\left(\theta_{j}^{* i} x_{j}\right)\right]$

teljesül, akkor $a\left\{\theta_{a j}^{* i}, \theta_{b j}^{* i}, \theta_{0}^{* i}, c_{0}^{* i}, c_{1}^{* i}, t_{j}^{*}\right\}$ egyensúlymarad, ha a piaci szereplök a (2) optimalizálási feladat szerint döntenek.

A triviális állítás azt az esetet fogalmazza meg, amikor a szabályozói előírás nélkül meghatározott optimum teljesíti az elöírt szabályozói korlátot, azaz a szabályozói 
elóírás redundáns. Ekkor az eredeti egyensúly elérhető marad, az árjegyző optimális döntése nem változik, így a piaci likviditást megragadó endogén árrés is megegyezik a vizsgált két egyensúly esetében.

5. ÁLLítÁs • Legyen a $\left\{\theta_{a j}^{* i}, \theta_{b j}^{* i}, \theta_{0}^{* i}, c_{0}^{* i}, c_{1}^{* i}, t_{j}^{*}\right\}$ egyensúly, ahol $\theta_{a j}^{* i}, \theta_{b j}^{* i}, \theta_{0}^{* i}, c_{0}^{* i} e ́ s c_{1}^{* i}$ megoldása a piaci szereplők (1) optimalizálási feladatának, és tegyük fel, hogy létezik $i \in I$, amelyre

$\theta_{0}^{* \bar{i}}<\sum_{j \in J} \delta_{j} \max \left[0, E S_{k}\left(\theta_{j}^{* \bar{i}} x_{j}\right)\right]$.

Ekkora $\left\{\theta_{a j}^{* * i}, \theta_{b j}^{* * i}, \theta_{0}^{* * i}, c_{0}^{* * i}, c_{1}^{* * i}, t_{j}^{* *}\right\}$ egyensúly, ahol a piaci szereplök a (2) optimalizálási feladat szerint döntenek, nem egyezik meg $a\left\{\theta_{a j}^{* i}, \theta_{b j}^{* i}, \theta_{0}^{* i}, c_{0}^{* i}, c_{1}^{* i}, t_{j}^{*}\right\}$ egyensúllyal.

Ha a szabályozói előírás nélkül meghatározott optimumban van olyan szereplö, aki megsérti a szabályozói előírásként bevezetett korlátot, akkor számára a szabályozói elöírás bevezetése után már nem érhető el a korábban választott portfólió. A szabályozói előírás bevezetésének következtében megváltozik az egyensúly.

1. SEJTÉs. Tegyük fel, hogy $t_{j}=t \forall j \in J$-re, és az i-edik szereplö preferenciáit leíró $u^{i}$ : $\mathbb{R}^{S+1} \rightarrow \mathbb{R}$ hasznossági függvény folytonos és szigorúan monoton.

Legyen $\left\{\theta_{a j}^{* i}, \theta_{b j}^{* i}, \theta_{0}^{* i}, c_{0}^{* i}, c_{1}^{* i}, t^{*}\right\}$ egyensúly, ahol $\theta_{a j}^{* i}, \theta_{b j}^{* i}, \theta_{0}^{* i}, c_{0}^{* i}$ és $c_{1}^{* i}$ megoldása a piaci szereplök (1) optimalizálási feladatának, és $\left\{\theta_{a j}^{* * i}, \theta_{b j}^{* * i}, \theta_{0}^{* * i}, c_{0}^{* * i}, c_{1}^{* * i}, t^{* *}\right\}$ egyensúly, ahol a $\theta_{a j}^{* * i}, \theta_{b j}^{* * i}, \theta_{0}^{* * i}, c_{0}^{* * i}$ és $c_{1}^{* * i}$ megoldása a piaci szereplők (2) optimalizálási feladatának. Tegyük fel továbbá, hogy létezik $\bar{i} \in I$, amelyre

$\theta_{0}^{* \bar{i}}<\sum_{j \in J} \delta_{j} \max \left[0, E S_{k}\left(\theta_{j}^{* \bar{i}} x_{j}\right)\right]$.

Ekkor

1. $\theta_{0}^{* * \bar{i}}=\sum_{j \in J} \delta_{j} \max \left[0, E S_{k}\left(\theta_{j}^{* * \bar{i}} x_{j}\right)\right]$,

2. $u^{i}\left(c_{0}^{* i i}, c_{1}^{* * i}\right) \leq u^{i}\left(c_{0}^{* i}, c_{1}^{* i}\right) \forall i \in I$ esetén, és $u^{\bar{i}}\left(c_{0}^{* * \bar{i}}, c_{1}^{* \bar{i}}\right)<u^{\bar{i}}\left(c_{0}^{* \bar{i}}, c_{1}^{* \bar{i}}\right)$,

3. $t^{* *}>t^{*}$.

Szigorúan monoton hasznossági függvény feltevése mellett az új portfóliót választó piaci szereplőkre vonatkozó szabályozási elöírás kötni fog (1. sEjTÉs 1. pont), hasznosságuk pedig csökken, mert az új portfóliót előtte is választhatták volna (1. SEJTÉs 2. pont). A piaci szereplők hasznossága nem nőhet, hiszen a döntési lehetőségeik halmaza nem változik vagy szükül. Amíg köt a korlát, addig a piaci szereplők nem tudnak olyan mennyiséget venni/eladni az eszközökből, ami a szabályozói elöírás nélkül optimális volt, ezért a kereskedett mennyiség növelése nem tudja kompenzálni az árrés csökkentése miatt kieső bevételt. Az árjegyző magasabb profitot tud elérni az árrés emelésével (1. SEJTÉs 3. pont). Az árrést egészen addig emeli az árjegyző, amíg a szabályozói elöírás redundánssá válik. 


\section{A modell két piaci szereplővel}

A következőkben feltesszük, hogy két piaci szereplő kereskedik egymással, miközben az árjegyző csak közvetít, nem tart eszközöket. A kereskedés célja, hogy a szereplők simítsák fogyasztásukat a két időszak és a különböző világállapotok között. A kereskedés feltétele, hogy a készletek vagy a hasznossági függvények különbözzenek. Célunk, hogy a speciális eset levezetésén és példákon keresztül megvizsgáljuk, hogy szabályozói előírás bevezetésének hatására hogyan módosítják döntésüket a szereplők, és ennek következtében hogyan változik az egyensúly.

Két piaci szereplö, J eszköz és S világállapot

Tegyük fel, hogy $|I|=2$, azaz legyen két piaci szereplőnk. Az $i$-edik szereplő fogyasztási és portfólióallokálási döntése:

$\max _{c_{0}^{i}, c_{1}^{i}, \theta_{a}^{i}, \theta_{b}^{i}, \theta_{0}^{i}} u^{i}\left(c_{0}^{i}, c_{1}^{i}\right)$,

feltéve, hogy

$c_{0}^{i} \leq \omega_{0}^{i}-\theta_{a}^{i} a+\theta_{b}^{i} b-\theta_{0}^{i}$

$c_{1}^{i} \leq \omega_{1}^{i}+\left(\theta_{a}^{i}-\theta_{b}^{i}\right) X+\theta_{0}^{i} 1^{s}$

$\theta_{a}^{i} \geq 0$

$\theta_{b}^{i} \geq 0$.

Amikor a tőkepiac egyensúlyban van, a piactisztító feltétel alapján az optimális portfóliókra teljesül, hogy

$\theta^{1}+\theta^{2}=\theta_{a}^{1}-\theta_{b}^{1}+\theta_{a}^{2}-\theta_{b}^{2}=0$,

azaz $-\theta_{j}^{1}=\theta_{j}^{2} \forall j \in J$ kockázatos eszközre. Az 1 . ÁLLíTÁs értelmében a költségvetési korlátok összegzése biztosítja tőkepiaci egyensúly esetén a fogyasztási piacok egyensúlyát. Az árjegyző a $t_{j}$ árrésről $(\forall j \in J$ eszközre) döntve maximalizálja a tranzakciós költségfüggvények összegét:

$\max _{t_{j} \forall j \in J} \sum_{j \in J} t_{j}\left(\theta_{a j}^{1}+\theta_{a j}^{2}\right)$,

és elfogyasztja profitját a 0 -adik időszakban. Egyensúlyban az optimális árrés nem lehet negatív az 1. LEMMA értelmében. Ezért, ha a kereskedő piaci szereplők hasznossági függvénye szigorúan monoton, akkor sosem éri meg egyszerre venni és eladni ugyanazt az eszközt: $\theta_{a j}^{1} \theta_{b j}^{1}=0$ és $\theta_{a j}^{2} \theta_{b 2}^{2}=0$ (3. ÁLLÍTÁs).

A kétszereplős modellt módosíthatjuk, ha a piaci szereplőknek teljesíteniük kell a likvid eszközök tartását elöíró szabályt. A szabályozás szerepeltetése $\theta_{0}^{i} \geq \sum_{j \in J} \delta_{j} \max \left[0, E S_{k}\left(\theta_{j}^{i} x_{j}\right)\right]$ 
feltétellel módosítja az i-edik szereplő fogyasztási és portfólióallokálási döntését, ugyanakkor a szabályozás nem változtat az egyensúly piactisztító feltételein.

\section{Speciális kétszereplős modell megoldása}

Legyen a modellben $|I|=2,|J|=2$, és $|S|=2$ az 1 . időszakban, azaz két szereplö, két eszköz és két világállapot. A két világállapot bekövetkezésének valószínüsége megegyezik $\left(\pi_{1}=\pi_{2}=1 / 2\right)$. A két eszköz kifizetése legyen $x_{1}=\left[x_{11},-x_{11}\right]$ és $x_{2}=\left[-x_{22}, x_{22}\right]$. Tegyük fel továbbá, hogy a két piaci szereplő különböző jövőbeli világállapotban realizál pozitív készletet, azaz $\omega_{11}^{1}>0$ és $\omega_{12}^{1}=0$, illetve $\omega_{11}^{2}=0$ és $\omega_{12}^{2}>0$. Ekkor $x_{11}>0$ és $x_{22}>0$ esetén az első szereplő kizárólag a második eszközt $\left(\theta_{a 1}^{1}=0, \theta_{b 2}^{1}=0\right)$, míg a második szereplő az első eszközt veszi $\left(\theta_{a 2}^{2}=0, \theta_{b 1}^{2}=0\right)$.

Logaritmikus hasznossági függvényt feltételezve írjuk fel a fogyasztási és portfólióallokálási döntést. Ekkor a hasznossági függvény szigorú monotonitása miatt a költségvetési korlátok egyenlőséggel teljesülnek, és a $c_{0}$ és $c_{1}$ fogyasztás szigorúan pozitív. A szabályozási elöírásként bevezetett korlát egyszerüsödik, mivel a két világállapot esetén az $E S$ számításakor $k=1$. A maximalizálási problémák a következő alakban adhatók meg: ${ }^{7}$

$\max _{c_{0}^{1}, c_{1}^{1}} \ln \left(c_{0}^{1}\right)+\frac{1}{2} \ln \left(c_{11}^{1}\right)+\frac{1}{2} \ln \left(c_{12}^{1}\right)$,

feltéve, hogy

$$
\begin{aligned}
c_{0}^{1} & =\omega_{0}^{1}+\theta_{b 1}^{1} b_{1}-\theta_{a 2}^{1} a_{2}-\theta_{0}^{1} \\
\theta_{0}^{1} & \geq \delta_{1}\left(\frac{1}{2} \theta_{b 1}^{1} x_{11}\right)+\delta_{2}\left(\frac{1}{2} \theta_{a 2}^{1} x_{22}\right) \\
c_{11}^{1} & =\omega_{11}^{1}-\theta_{b 1}^{1} x_{11}+\theta_{a 2}^{1} x_{22}+\theta_{0}^{1} \\
c_{12}^{1} & =\theta_{b 1}^{1} x_{11}+\theta_{a 2}^{1} x_{22}+\theta_{0}^{1} \\
\theta_{a 2}^{1} & \geq 0 \\
\theta_{b 1}^{1} & \geq 0 \\
c_{0}^{1} & >0 \\
c_{1}^{1} & >0,
\end{aligned}
$$

és

$$
\max _{c_{0}^{2}, c_{1}^{2}} \ln \left(c_{0}^{2}\right)+\frac{1}{2} \ln \left(c_{11}^{2}\right)+\frac{1}{2} \ln \left(c_{12}^{2}\right),
$$

${ }^{7}$ A fogyasztás szigorú pozitivitása miatt az optimalizálási problémákban két feltétel szigorú egyenlőtlenség formájában adott, ezért a lehetséges megoldások halmaza nem zárt. Ha az egyensúlyi megoldás nem teljesíti a szigorú egyenlőtlenséget, akkor nincs globális maximuma az optimalizálási feladatoknak. A példában a fogyasztás pozitivitását csak az optimalizálás után ellenőrizzük. 
feltéve, hogy

$$
\begin{aligned}
c_{0}^{2} & =\omega_{0}^{2}+\theta_{b 2}^{2} b_{2}-\theta_{a 1}^{2} a_{1}-\theta_{0}^{2} \\
\theta_{0}^{2} & \geq \delta_{1}\left(\frac{1}{2} \theta_{a 1}^{2} x_{11}\right)+\delta_{2}\left(\frac{1}{2} \theta_{b 2}^{2} x_{22}\right) \\
c_{11}^{2} & =\theta_{b 2}^{2} x_{22}+\theta_{a 1}^{2} x_{11}+\theta_{0}^{2} \\
c_{12}^{2} & =\omega_{12}^{2}-\theta_{b 2}^{2} x_{22}-\theta_{a 1}^{2} x_{11}+\theta_{0}^{2} \\
\theta_{a 1}^{2} & \geq 0 \\
\theta_{b 2}^{2} & \geq 0 \\
c_{0}^{2} & >0 \\
c_{1}^{2} & >0 .
\end{aligned}
$$

Vegyük észre, hogy az első piaci szereplőnek az első jövőbeli világállapotban mindkét eszköz negatív kifizetést, míg a második világállapotban mindkét eszköz pozitív kifizetést biztosít. Mivel a két eszköz nem független egymástól, a megoldás során a két eszközből kikevert portfólió kifizetését határozzuk meg, a két eszköz egyensúlyi ára mellett a piaci szereplőnek mindegy, hogy a két eszközből hogyan keveri ki a keresett portfóliót.

Helyettesítsük be az egyenlőséggel adott feltételeket a hasznossági függvényekbe a $c_{0}^{1}, c_{11}^{1}, c_{12}^{1}, c_{0}^{2}, c_{11}^{2}$ és $c_{12}^{2}$ fogyasztás helyére, és írjuk fel a Lagrange-függvényeket a feltételes optimalizáláshoz:

$$
\begin{aligned}
& G\left(\theta_{b 1}^{1}, \theta_{a 2}^{1}, \theta_{0}^{1}, \gamma_{1}, \lambda_{1}, \mu_{1}\right)=\ln \left(\omega_{0}^{1}+\theta_{b 1}^{1} b_{1}-\theta_{a 2}^{1} a_{2}-\theta_{0}^{1}\right)+ \\
& +\frac{1}{2} \ln \left(\omega_{11}^{1}-\theta_{b 1}^{1} x_{11}-\theta_{a 2}^{1} x_{22}+\theta_{0}^{1}\right)+\frac{1}{2} \ln \left(\theta_{b 1}^{1} x_{11}+\theta_{a 2}^{1} x_{22}+\theta_{0}^{1}\right)+ \\
& +\gamma_{1}\left[\theta_{0}^{1}-\delta_{1}\left(\frac{1}{2} \theta_{b 1}^{1} x_{11}\right)-\delta_{2}\left(\frac{1}{2} \theta_{a 2}^{1} x_{22}\right)\right]+\lambda_{1} \theta_{b 1}^{1}+\mu_{1} \theta_{a 2}^{1}, \\
& G\left(\theta_{b 2}^{2}, \theta_{a 1}^{2}, \theta_{0}^{2}, \gamma_{2}, \lambda_{2}, \mu_{2}\right)=\ln \left(\omega_{0}^{2}+\theta_{b 2}^{2} b_{2}-\theta_{a 1}^{2} a_{1}-\theta_{0}^{2}\right)+ \\
& +\frac{1}{2} \ln \left(\theta_{b 2}^{2} x_{22}+\theta_{a 1}^{2} x_{11}+\theta_{0}^{2}\right)+\frac{1}{2} \ln \left(\omega_{12}^{2}-\theta_{b 2}^{2} x_{22}-\theta_{a 1}^{2} x_{11}+\theta_{0}^{2}\right)+ \\
& +\gamma_{2}\left[\theta_{0}^{2}-\delta_{1}\left(\frac{1}{2} \theta_{a 1}^{2} x_{11}\right)-\delta_{2}\left(\frac{1}{2} \theta_{b 2}^{2} x_{22}\right)\right]+\lambda_{2} \theta_{b 2}^{2}+\mu_{2} \theta_{a 1}^{2},
\end{aligned}
$$

ahol $\gamma_{1}, \gamma_{2}, \lambda_{1}, \lambda_{2}, \mu_{1}$ és $\mu_{2}$ a Lagrange-szorzók. Az első szereplő optimalizálási problémájának Karush-Kuhn-Tucker-feltételei:

$$
\frac{\partial G\left(\theta_{b 1}^{1}, \theta_{a 2}^{1}, \theta_{0}^{1}, \gamma_{1}, \lambda_{1}, \mu_{1}\right)}{\partial \theta_{b 1}^{1}}=\frac{b_{1}}{c_{0}^{1}}+\frac{-x_{11}}{2 c_{11}^{1}}+\frac{x_{11}}{2 c_{12}^{1}}-\gamma_{1} \delta_{1} \frac{1}{2} x_{11}+\lambda_{1}=0
$$




$$
\begin{aligned}
& \frac{\partial G\left(\theta_{b 1}^{1}, \theta_{a 2}^{1}, \theta_{0}^{1}, \gamma_{1}, \lambda_{1}, \mu_{1}\right)}{\partial \theta_{a 2}^{1}}=\frac{-a_{2}}{c_{0}^{1}}+\frac{-x_{22}}{2 c_{11}^{1}}+\frac{x_{22}}{2 c_{12}^{1}}-\gamma_{1} \delta_{2} \frac{1}{2} x_{22}+\mu_{1}=0 \\
& \frac{\partial G\left(\theta_{b 1}^{1}, \theta_{a 2}^{1}, \theta_{0}^{1}, \gamma_{1}, \lambda_{1}, \mu_{1}\right)}{\partial \theta_{0}^{1}}=\frac{-1}{c_{0}^{1}}+\frac{1}{2 c_{11}^{1}}+\frac{1}{2 c_{12}^{1}}+\gamma_{1}=0 \\
& \frac{\partial G\left(\theta_{b 1}^{1}, \theta_{a 2}^{1}, \theta_{0}^{1}, \gamma_{1}, \lambda_{1}, \mu_{1}\right)}{\partial \gamma_{1}}=\theta_{0}^{1}-\delta_{1}\left(\frac{1}{2} \theta_{b 1}^{1} x_{11}\right)-\delta_{2}\left(\frac{1}{2} \theta_{a 2}^{1} x_{22}\right) \geq 0 \\
& \frac{\partial G\left(\theta_{b 1}^{1}, \theta_{a 2}^{1}, \theta_{0}^{1}, \gamma_{1}, \lambda_{1}, \mu_{1}\right)}{\partial \lambda_{1}}=\theta_{b 1}^{1} \geq 0 \\
& \frac{\partial G\left(\theta_{b 1}^{1}, \theta_{a 2}^{1}, \theta_{0}^{1}, \gamma_{1}, \lambda_{1}, \mu_{1}\right)}{\partial \mu_{1}}=\theta_{a 2}^{1} \geq 0 .
\end{aligned}
$$

A komplementaritás és a Lagrange-szorzók nemnegativitása miatt

$$
\begin{aligned}
\gamma_{1}\left[\theta_{0}^{1}-\delta_{1}\left(\frac{1}{2} \theta_{b 1}^{1} x_{11}\right)-\delta_{2}\left(\frac{1}{2} \theta_{a 2}^{1} x_{22}\right)\right] & =0 \\
\lambda_{1}\left[\theta_{b 1}^{1}\right] & =0 \\
\mu_{1}\left[\theta_{a 2}^{1}\right] & =0 \\
\gamma_{1} & \geq 0 \\
\lambda_{1} & \geq 0 \\
\mu_{1} & \geq 0 .
\end{aligned}
$$

A második szereplő optimalizálási problémájának Karush-Kuhn-Tucker-feltételei:

$$
\begin{aligned}
& \frac{\partial G\left(\theta_{b 2}^{2}, \theta_{a 1}^{2}, \theta_{0}^{2}, \gamma_{2}, \lambda_{2}, \mu_{2}\right)}{\partial \theta_{b 2}^{2}}=\frac{b_{2}}{c_{0}^{2}}+\frac{x_{22}}{2 c_{11}^{2}}+\frac{-x_{22}}{2 c_{12}^{2}}-\gamma_{2} \delta_{2} \frac{1}{2} x_{22}+\lambda_{2}=0 \\
& \frac{\partial G\left(\theta_{b 2}^{2}, \theta_{a 1}^{2}, \theta_{0}^{2}, \gamma_{2}, \lambda_{2}, \mu_{2}\right)}{\partial \theta_{a 1}^{2}}=\frac{-a_{1}}{c_{0}^{2}}+\frac{x_{11}}{2 c_{11}^{2}}+\frac{-x_{11}}{2 c_{12}^{2}}-\gamma_{2} \delta_{1} \frac{1}{2} x_{11}+\mu_{2}=0 \\
& \frac{\partial G\left(\theta_{b 2}^{2}, \theta_{a 1}^{2}, \theta_{0}^{2}, \gamma_{2}, \lambda_{2}, \mu_{2}\right)}{\partial \theta_{0}^{2}}=\frac{-1}{c_{0}^{2}}+\frac{1}{2 c_{11}^{2}}+\frac{1}{2 c_{12}^{2}}+\gamma_{2}=0 \\
& \frac{\partial G\left(\theta_{b 2}^{2}, \theta_{a 1}^{2}, \theta_{0}^{2}, \gamma_{2}, \lambda_{2}, \mu_{2}\right)}{\partial \gamma_{2}}=\theta_{0}^{2}-\delta_{1}\left(\frac{1}{2} \theta_{a 1}^{2} x_{11}\right)-\delta_{2}\left(\frac{1}{2} \theta_{b 2}^{2} x_{22}\right) \geq 0 \\
& \frac{\partial G\left(\theta_{b 2}^{2}, \theta_{a 1}^{2}, \theta_{0}^{2}, \gamma_{2}, \lambda_{2}, \mu_{2}\right)}{\partial \lambda_{2}}=\theta_{b 2}^{2} \geq 0 \\
& \frac{\partial G\left(\theta_{b 2}^{2}, \theta_{a 1}^{2}, \theta_{0}^{2}, \gamma_{2}, \lambda_{2}, \mu_{2}\right)}{\partial \mu_{2}}=\theta_{a 1}^{2} \geq 0 .
\end{aligned}
$$


A komplementaritás és a Lagrange-szorzók nemnegativitása miatt

$$
\begin{aligned}
\gamma_{2}\left[\theta_{0}^{2}-\delta_{1}\left(\frac{1}{2} \theta_{a 1}^{2} x_{11}\right)-\delta_{2}\left(\frac{1}{2} \theta_{b 2}^{2} x_{22}\right)\right] & =0 \\
\lambda_{2}\left[\theta_{b 2}^{2}\right] & =0 \\
\mu_{2}\left[\theta_{a 1}^{2}\right] & =0 \\
\gamma_{2} & \geq 0 \\
\lambda_{2} & \geq 0 \\
\mu_{2} & \geq 0 .
\end{aligned}
$$

A megoldás során első lépésként feltesszük, hogy a komplementaritás teljesüléséhez $\gamma_{1}, \lambda_{1}, \mu_{1}, \gamma_{2}, \lambda_{2}$ és $\mu_{2}$ értéke 0 . Ekkor az egyenlőtlenségként megadott feltételek nélkül megoldhatjuk a maximalizálási problémákat, majd ellenőrizhetjük, hogy az így kapott optimális megoldás valóban teljesíti-e a korlátozó feltételeket. Ha teljesíti, akkor az egyenlőtlenség formájában megadott korlátozó feltételek - köztük a szabályozói elóírás - nem módosítanak az egyensúlyon, hiszen nem befolyásolják a piaci szereplők döntését (4. ÁLLíTÁs). Ha a szabályozói elöírás nem teljesül, akkor a kiinduló feltevésünk, miszerint egyensúlyban $\gamma_{1}=0$ és $\gamma_{2}=0$, hamis. A modellt

$$
\begin{aligned}
& \theta_{0}^{1}=\delta_{1}\left(\frac{1}{2} \theta_{b 1}^{1} x_{11}\right)+\delta_{2}\left(\frac{1}{2} \theta_{a 2}^{1} x_{22}\right) \\
& \theta_{0}^{2}=\delta_{1}\left(\frac{1}{2} \theta_{a 1}^{2} x_{11}\right)+\delta_{2}\left(\frac{1}{2} \theta_{b 2}^{2} x_{22}\right) \\
& \gamma_{1}>0 \\
& \gamma_{2}>0
\end{aligned}
$$

feltételek mellett kell megoldanunk. Ekkor a szabályozói előírás bevezetése új egyensúlyt eredményez (5. ÁLLíTÁs).

A REDUNDÁNS SZABÁLYOzói ELÖÍRÁS ESETE • Tegyük fel, hogy a szabályozói elöírás bevezetése nem módosítja a piaci szereplők optimális döntését (4. ÁLLíTÁs). Az egyszerüsödött elsőrendü feltételek, $\gamma_{1}=0, \lambda_{1}=0, \mu_{1}=0, \gamma_{2}=0, \lambda_{2}=0$ és $\mu_{2}=0$ esetén:

$$
\begin{aligned}
& \frac{b_{1}}{c_{0}^{1}}+\frac{-x_{11}}{2 c_{11}^{1}}+\frac{x_{11}}{2 c_{12}^{1}}=0 \\
& \frac{-a_{2}}{c_{0}^{1}}+\frac{-x_{22}}{2 c_{11}^{1}}+\frac{x_{22}}{2 c_{12}^{1}}=0 \\
& \frac{-1}{c_{0}^{1}}+\frac{1}{2 c_{11}^{1}}+\frac{1}{2 c_{12}^{1}}=0
\end{aligned}
$$


$\frac{-a_{1}}{c_{0}^{2}}+\frac{x_{11}}{2 c_{11}^{2}}+\frac{-x_{11}}{2 c_{12}^{2}}=0$

$\frac{b_{2}}{c_{0}^{2}}+\frac{x_{22}}{2 c_{11}^{2}}+\frac{-x_{22}}{2 c_{12}^{2}}=0$

$\frac{-1}{c_{0}^{2}}+\frac{1}{2 c_{11}^{2}}+\frac{1}{2 c_{12}^{2}}=0$.

A logaritmikus hasznossági függvény alkalmazása és a kockázatmentes eszközről történő döntés következtében a különböző időszaki fogyasztások között a következő harmonikus átlagszerü összefüggések adódnak:

$$
\begin{aligned}
& c_{0}^{1}=\frac{2}{\frac{1}{c_{11}^{1}}+\frac{1}{c_{12}^{1}}}, \\
& c_{0}^{2}=\frac{2}{\frac{1}{c_{11}^{2}}+\frac{1}{c_{12}^{2}}} .
\end{aligned}
$$

Az elsőrendü feltételeket a fogyasztás helyett a megtakarított kockázatmentes eszköz $\left(\theta_{0}^{1}, \theta_{0}^{2}\right)$, a portfóliók $\left(\theta_{b 1}^{1}, \theta_{a 2}^{1}, \theta_{a 1}^{2}, \theta_{b 2}^{2}\right)$ és a készletek $\left(\omega_{11}^{1}, \omega_{12}^{2}\right)$ függvényében is megadhatjuk:

$$
\begin{aligned}
b_{1}\left(\omega_{11}^{1}+2 \theta_{0}^{1}\right) & =x_{11}\left(2 \theta_{b 1}^{1} x_{11}+2 \theta_{a 2}^{1} x_{22}-\omega_{11}^{1}\right) \\
-a_{2}\left(\omega_{11}^{1}+2 \theta_{0}^{1}\right) & =x_{22}\left(2 \theta_{b 1}^{1} x_{11}+2 \theta_{a 2}^{1} x_{22}-\omega_{11}^{1}\right) \\
-a_{1}\left(\omega_{12}^{2}+2 \theta_{0}^{2}\right) & =x_{11}\left(2 \theta_{b 2}^{2} x_{22}+2 \theta_{a 1}^{2} x_{11}-\omega_{12}^{2}\right) \\
b_{2}\left(\omega_{12}^{2}+2 \theta_{0}^{2}\right) & =x_{22}\left(2 \theta_{b 2}^{2} x_{22}+2 \theta_{a 1}^{2} x_{11}-\omega_{12}^{2}\right) .
\end{aligned}
$$

Ekkor az egyensúly meghatározásához szükségünk lesz a fogyasztások közötti harmonikus átlag összefüggésére is a portfóliók és a készletek függvényében felírva:

$$
\begin{aligned}
& \left(\omega_{0}^{1}+\theta_{b 1}^{1} b_{1}-\theta_{a 2}^{1} a_{2}-\theta_{0}^{1}\right)\left(\omega_{11}^{1}+2 \theta_{0}^{1}\right)=2\left(\omega_{11}^{1}-\theta_{b 1}^{1} x_{11}-\theta_{a 2}^{1} x_{22}+\theta_{0}^{1}\right)\left(\theta_{b 1}^{1} x_{11}+\theta_{a 2}^{1} x_{22}+\theta_{0}^{1}\right) \\
& \left(\omega_{0}^{2}+\theta_{b 2}^{2} b_{2}-\theta_{a 1}^{2} a_{1}-\theta_{0}^{2}\right)\left(\omega_{12}^{2}+2 \theta_{0}^{2}\right)=2\left(\omega_{12}^{2}-\theta_{b 2}^{2} x_{22}-\theta_{a 1}^{2} x_{11}+\theta_{0}^{2}\right)\left(\theta_{b 2}^{2} x_{22}+\theta_{a 1}^{2} x_{11}+\theta_{0}^{2}\right) .
\end{aligned}
$$

A továbbiakban közvetlen kereskedés ( 0 árrés) és árjegyző közvetítése (exogén, illetve endogén árrés) mellett egyaránt vizsgáljuk a megoldást.

Egyensúly árjegyző közvetítése nélkül • Tegyük fel, hogy a kereskedés közvetlenül történik, és nincs árrés. Akkor és csak akkor lehet $b_{1}=b_{2}=a_{1}=a_{2}=0$, ha $c_{11}^{1}=c_{12}^{1}=c_{0}^{1}$ és $c_{11}^{2}=c_{12}^{2}=c_{0}^{2}$. Ekkor 
$\omega_{0}^{1}-\theta_{0}^{1}=\omega_{11}^{1}-\theta_{b 1}^{1} x_{11}-\theta_{a 2}^{1} x_{22}+\theta_{0}^{1}$

$\omega_{11}^{1}-\theta_{b 1}^{1} x_{11}-\theta_{a 2}^{1} x_{22}=\theta_{b 1}^{1} x_{11}+\theta_{a 2}^{1} x_{22}$

$\omega_{0}^{2}-\theta_{0}^{2}=\theta_{b 2}^{2} x_{22}+\theta_{a 1}^{2} x_{11}+\theta_{0}^{2}$

$\theta_{b 2}^{2} x_{22}+\theta_{a 1}^{2} x_{11}=\omega_{12}^{2}-\theta_{a 1}^{2} x_{11}-\theta_{b 2}^{2} x_{22}$.

Kifejezve a két piaci szereplő által megtakarított kockázatmentes eszköz, $\theta_{0}^{1}$ és $\theta_{0}^{2}$ értékét:

$\theta_{0}^{1}=\frac{\omega_{0}^{1}-\frac{\omega_{11}^{1}}{2}}{2}$

$\theta_{0}^{2}=\frac{\omega_{0}^{2}-\frac{\omega_{12}^{2}}{2}}{2}$,

meghatározhatjuk az optimális fogyasztást:

$c_{11}^{1}=c_{12}^{1}=c_{0}^{1}=\frac{\omega_{11}^{1}}{4}+\frac{\omega_{0}^{1}}{2}$

$c_{11}^{2}=c_{12}^{2}=c_{0}^{2}=\frac{\omega_{12}^{1}}{4}+\frac{\omega_{0}^{2}}{2}$.

A szereplők úgy optimalizálnak, hogy az első időszaki készlet felét realizálják mindkét jövőbeli világállapotban:

$\theta_{a 2}^{1} x_{22}+\theta_{b 1}^{1} x_{11}=\frac{\omega_{11}^{1}}{2}$

$\theta_{b 2}^{2} x_{22}+\theta_{a 1}^{2} x_{11}=\frac{\omega_{12}^{2}}{2}$,

ezzel tökéletesen kiküszöbölve a bizonytalanságból eredő kockázatot és tökéletesen simítva a fogyasztást. Tőkepiaci egyensúly esetén $\theta_{b 1}^{1}=\theta_{a 1}^{2}$ és $\theta_{a 1}^{1}=\theta_{b 2}^{2}$, ezért a szimmetria miatt csak akkor lesz a feltételezett $b_{1}=b_{2}=a_{1}=a_{2}=0$ árrendszer egyensúlyi, ha

$\omega_{11}^{1}=\omega_{12}^{2}$.

Abból indultunk ki, hogy egyensúly esetén teljesülnek az egyenlötlenséggel megadott korlátozó feltételek. Ezért az ellentmondás elkerülése érdekében meg kell vizsgálnunk, hogy a szabályozói elóírás miatt bevezetett korlátot teljesíti-e a szabályozói elöírás nélkül meghatározott optimum, azaz

$$
\begin{aligned}
& \theta_{0}^{1}>\delta_{1}\left(\frac{1}{2} \theta_{b 1}^{1} x_{11}\right)+\delta_{2}\left(\frac{1}{2} \theta_{a 2}^{1} x_{22}\right) \\
& \theta_{0}^{2}>\delta_{1}\left(\frac{1}{2} \theta_{a 1}^{2} x_{11}\right)+\delta_{2}\left(\frac{1}{2} \theta_{b 2}^{2} x_{22}\right)
\end{aligned}
$$


mikor áll fenn. Ha $\delta=\delta_{1}=\delta_{2}$ és $\omega_{0}^{1}=\omega_{0}^{2}$, akkor

$\delta<\frac{2 \theta_{0}^{1}}{\theta_{b 1}^{1} x_{11}+\theta_{a 2}^{1} x_{22}}=\frac{4 \theta_{0}^{1}}{\omega_{11}^{1}}=\frac{\omega_{0}^{1}-\frac{\omega_{11}^{1}}{2}}{\frac{\omega_{11}^{1}}{2}}$.

Amíg a szabályozói paraméter értéke kisebb, mint a jelenbeli és a jövőbeli világállapotban várható készlet különbsége a jövőbeli világállapotban várható készlethez viszonyítva, addig a szabályozói elöírás bevezetésének hatására nem módosul a piaci szereplők döntése és az elérhető hasznosság szintje sem. Ezzel szemben, ha túl magas a szabályozói paraméter értéke, akkor egyensúly esetén $\gamma_{1}$ és $\gamma_{2}$ értéke nem lehetett 0 , ellentmondáshoz jutottunk.

Megoldás árrés mellett $\bullet$ Következő lépésként tegyük fel, hogy $b_{1}=a_{1}-t_{1}$ és $b_{2}=a_{2}-t_{2}$, ahol $t_{1}$ és $t_{2}$ exogén árrés. Ekkor

$$
\begin{aligned}
& \left(a_{1}-t_{1}\right)\left(\omega_{11}^{1}+2 \theta_{0}^{1}\right)=x_{11}\left(2 \theta_{b 1}^{1} x_{11}+2 \theta_{a 2}^{1} x_{22}-\omega_{11}^{1}\right) \\
& \left(-a_{2}\right)\left(\omega_{11}^{1}+2 \theta_{0}^{1}\right)=x_{22}\left(2 \theta_{b 1}^{1} x_{11}+2 \theta_{a 2}^{1} x_{22}-\omega_{11}^{1}\right) \\
& \left(-a_{1}\right)\left(\omega_{12}^{2}+2 \theta_{0}^{2}\right)=x_{11}\left(2 \theta_{a 2}^{1} x_{22}+2 \theta_{b 1}^{1} x_{11}-\omega_{12}^{2}\right) \\
& \left(a_{2}-t_{2}\right)\left(\omega_{12}^{2}+2 \theta_{0}^{2}\right)=x_{22}\left(2 \theta_{a 2}^{1} x_{22}+2 \theta_{b 1}^{1} x_{11}-\omega_{12}^{2}\right) .
\end{aligned}
$$

Alakítsuk a piaci szereplők elsőrendű feltételeit. Ha $b_{1}, b_{2}, a_{1}$ és $a_{2}$ nem nulla, mivel a fogyasztás pozitivitása miatt $\omega_{11}^{1}+2 \theta_{0}^{1} \neq 0, \omega_{12}^{2}+2 \theta_{0}^{2} \neq 0$, ezért

$$
\begin{aligned}
& \frac{x_{11}}{x_{22}}=\frac{b_{1}}{-a_{2}}=\frac{a_{1}-t_{1}}{-a_{2}} \\
& \frac{x_{11}}{x_{22}}=\frac{-a_{1}}{b_{2}}=\frac{-a_{1}}{a_{2}-t_{2}} .
\end{aligned}
$$

A vételi árak ( $a_{1}$ és $\left.a_{2}\right)$ előjele pozitív, míg az eladási árak $\left(b_{1}\right.$ és $\left.b_{2}\right)$ negatív előjelüek. Átalakítva

$$
t_{2}=\frac{x_{22}}{x_{11}} t_{1}
$$

azaz az egyensúly létezésének feltétele, hogy a két exogén árrés aránya megegyezzen a kifizetések arányával. $\mathrm{Ha} \omega_{0}^{1}=\omega_{0}^{2}$ és $\omega_{11}^{1}=\omega_{12}^{2}$, akkor

$$
\begin{aligned}
& a_{1}=\frac{t_{1}}{2} \\
& a_{2}=\frac{t_{2}}{2}=\frac{x_{22}}{x_{11}} \frac{t_{1}}{2}=\frac{x_{22}}{x_{11}} a_{1} .
\end{aligned}
$$


Az egyensúlyi árak kialakulása esetén az egyensúlyi portfóliókra a következő összefüggés teljesül:

$$
\frac{-\frac{t_{1}}{2}}{x_{11}}=\frac{\theta_{b 1}^{1} x_{11}+\theta_{a 2}^{1} x_{22}-\frac{\omega_{11}^{1}}{2}}{\theta_{0}^{1}+\frac{\omega_{11}^{1}}{2}} .
$$

Abban az esetben, amikor az árrés 0 volt, optimumban a kereskedésen keresztül a jövőbeli készlet felét cserélték el egymás között a szereplők, így tökéletesen simítva a jövőbeli bizonytalan kifizetést és ezzel a fogyasztást is. Árrés esetén csökken a piaci szereplök közötti kockázatmegosztás, és kockázatosabb marad a fogyasztási profil. Ha felírjuk a fogyasztások közötti harmonikusátlag-összefüggést:

$$
\begin{aligned}
& \left(\omega_{0}^{1}-\theta_{b 1}^{1} \frac{t_{1}}{2}-\theta_{a 2}^{1} \frac{x_{22}}{x_{11}} \frac{t_{1}}{2}-\theta_{0}^{1}\right)\left(\theta_{0}^{1}+\frac{\omega_{11}^{1}}{2}\right)= \\
& =\left(\omega_{11}^{1}-\theta_{b 1}^{1} x_{11}-\theta_{a 2}^{1} x_{22}+\theta_{0}^{1}\right)\left(\theta_{b 1}^{1} x_{11}+\theta_{a 2}^{1} x_{22}+\theta_{0}^{1}\right),
\end{aligned}
$$

a (27) és a (28) egyenlet megoldásával meghatározható az optimális $\theta_{0}^{1}$ és $\theta_{b 1}^{1} x_{11}+\theta_{a 2}^{1} x_{22}$ értéke és ezzel a $2 \theta_{0}^{1} /\left(\theta_{b 1}^{1} x_{11}+\theta_{a 2}^{1} x_{22}\right)$ korlát $\delta$-ra.

Megoldás árjegyzői döntés mellett • Az általános modellhez hasonlóan tegyük fel, hogy árjegyző párosítja az ellenoldali ajánlatokat, és a két eszközre $t_{1}$ és $t_{2}$ árrést határoz meg. Az árjegyző maximalizálási problémája:

$\max _{t_{1}, t_{2}} t_{1} \theta_{b 1}^{1}+t_{2} \theta_{a 2}^{1}$,

feltéve, hogy $\theta_{a 1}^{2}=\theta_{b 1}^{1}$ és $\theta_{a 2}^{1}=\theta_{b 2}^{2}$ megoldása a kereskedő piaci szereplők optimalizálási feladatainak, azaz teljesülnek a (22) és a (25) közötti elsőrendü feltételek, amelyek a (27) és a (28) egyenletekké alakíthatók. Az árjegyző maximalizálási problémája egyváltozós feladattá módosul a (26) összefüggés és $\Theta=\theta_{b 1}^{1} x_{11}+\theta_{a 2}^{1} x_{22}$ jelölés felhasználásával:

$$
\max _{t_{1}} \frac{t_{1}}{x_{11}} \Theta,
$$

feltéve, hogy

$$
\begin{aligned}
-\frac{t_{1}}{2}\left(\theta_{0}^{1}+\frac{\omega_{11}^{1}}{2}\right) & =x_{11}\left(\Theta-\frac{\omega_{11}^{1}}{2}\right) \\
\left(\omega_{0}^{1}-\frac{t_{1}}{2 x_{11}} \Theta-\theta_{0}^{1}\right)\left(\theta_{0}^{1}+\frac{\omega_{11}^{1}}{2}\right) & =\left(\omega_{11}^{1}-\Theta+\theta_{0}^{1}\right)\left(\Theta+\theta_{0}^{1}\right) .
\end{aligned}
$$

A vizsgált három esetben (árrés nélkül, exogén árrés és endogén árrés mellett) meghatározott egyensúly összevetését a következő példa illusztrálja. 
1. PÉLDA • A számpéldában a levezetett speciális esetet követve legyen $|I|=2$ szereplö, $|J|=2$ eszköz és $|S|=2$ világállapot az 1. idöszakban. A szereplők hasznossági függvénye megegyezik:

$u^{i}\left(c_{0}^{i}, c_{1}^{i}\right)=\ln \left(c_{0}^{i}\right)+\frac{1}{2} \ln \left(c_{11}^{i}\right)+\frac{1}{2} \ln \left(c_{12}^{i}\right)$,

készleteik pedig ellentétesek: $\omega_{0}^{1}=10, \omega_{1}^{1}=(20 ; 0)$ és $\omega_{0}^{2}=10, \omega_{1}^{2}=(0 ; 20)$. A két eszköz kifizetése legyen $x_{1}=(5 ;-5)$ és $x_{2}=(-5 ; 5)$. Jelölje $t_{1}$ és $t_{2}$ az árrések nagyságát. Elsö lépésként megoldjuk a szereplők fogyasztási portfólióallokálási feladatát, azaz a (27) és a (28) egyenletekböl álló egyenletrendszert, szabályozói elöirás nélkül, a t, exogén árrés különböző szintjei mellett. Majd módositjuk a példát endogén árrés bevezetésével. Ebben az esetben az árjegyző a (29) feladat alapján $\Pi=\left(t_{1} / x_{11}\right) \Theta$ profitját maximalizálja a $t_{1}$ árrés szerint, feltéve, hogy a két piaci szereplö hasznosságot maximalizál.

A példában a szereplők kereskedés segítségével fedezik várható kifizetéseiket és simítják fogyasztásukat az első időszak két világállapota között. Az 1. táblázat alapján árrés bevezetésekor, majd az árrés fokozatos növelésekor csökken a kereskedett eszközök jövőbeli kifizetése $(\Theta)$, míg a vételi árak emelkednek. Ennek eredményeként egyensúlyban a piaci szereplők alacsonyabb hasznossági szintet érnek el, és a fogyasztási profiljuk kockázatosabb marad. Ha az árrést az árjegyző határozza meg profitmaximalizálás alapján, akkor egyensúlyi értéke a példában 4,58. Ha az árrés 7,3205 fölé emelkedik, akkor nem kereskednek egymással a piaci szereplők.

\section{1. táblázat}

Eredmények exogén és endogén árrés esetén szabályozói előírás nélkül

\begin{tabular}{lccccccccc}
\hline$t_{1}=t_{2}$ & $b_{1}=b_{2}$ & $a_{1}=a_{2}$ & $\theta_{0}^{1}$ & $\Theta$ & $c_{0}^{1}$ & $c_{12}^{1}=c_{11}^{2}$ & $c_{11}^{1}=c_{12}^{2}$ & $u^{1}=u^{2}$ & $\Pi$ \\
\hline 0 & 0 & 0 & 0 & 10 & 10 & 10 & 10 & 4,6 & 0 \\
1 & $-0,5$ & 0,5 & $-0,4$ & 9,0 & 9,5 & 8,6 & 10,6 & 4,51 & 1,81 \\
2 & $-1,0$ & 1,0 & $-0,6$ & 8,1 & 9,0 & 7,5 & 11,2 & 4,41 & 3,25 \\
3 & $-1,5$ & 1,5 & $-0,7$ & 7,2 & 8,5 & 6,5 & 12,1 & 4,33 & 4,32 \\
4 & $-2,0$ & 2,0 & $-0,5$ & 6,2 & 8,0 & 5,7 & 13,3 & 4,25 & 4,95 \\
4,58 & $-2,3$ & 2,3 & $-0,2$ & 5,5 & 7,7 & 5,3 & 14,2 & 4,20 & 5,07 \\
5 & $-2,5$ & 2,5 & 0,0 & 5,0 & 7,5 & 5,0 & 15,0 & 4,17 & 5,00 \\
6 & $-3,0$ & 3,0 & 0,9 & 3,4 & 7,0 & 4,4 & 17,5 & 4,11 & 4,12 \\
7 & $-3,5$ & 3,5 & 2,7 & 1,1 & 6,5 & 3,8 & 21,7 & 4,08 & 1,51 \\
\hline
\end{tabular}

Meghatározhatjuk a szabályozói paraméter $\left(\delta=\delta_{1}=\delta_{2}\right)$ értékére a korlátot, amely szint alatt szabályozói előírás bevezetése esetén sem változik az eredeti egyensúly (2. táblázat). Jelen példában árrés nélkül a szabályozási elöírás bevezetése $\forall \delta>0$ esetén új egyensúly kialakulásához vezet, és a szabályozói elöírás egészen addig módosít mindenképpen az egyensúlyon, amíg az árrés 5 fölé emelkedik. Az árrés további növekedésekor a $\delta$-ra vonatkozó korlát értéke emelkedik, hiszen a készpénz-megtakarítás emelkedése miatt egyre magasabb szabályozói paraméter melletti szabályozói 
elöírásnak is megfelel a szabályozói elöírás nélkül kiszámított egyensúly. Ha az árrés szintje 6 , akkor redundáns a szabályozói követelmény, ha a $\delta<0,55$, azaz ha a portfólió eszközeire aggregált várható veszteség $(E S) 55$ százalékát nem éri el a tőkekövetelményként elvárt készpénz mennyisége.

\section{2. táblázat}

Korlát $\delta$ értékére az árrés különböző szintje mellett

\begin{tabular}{lc}
\hline$t_{1}=t_{2}$ & Korlát $\delta$ értékére \\
\hline 1 & $-0,09$ \\
2 & $-0,15$ \\
3 & $-0,18$ \\
4 & $-0,15$ \\
4,58 & $-0,09$ \\
5 & 0,00 \\
6 & 0,55 \\
7 & 5,09 \\
\hline
\end{tabular}

AZ EGYENSÚLYT MÓDOSító SZABÁLYOZÓi ELÖÍRÁs • Tegyük fel, hogy $\lambda_{1}, \mu_{1}, \lambda_{2}$ és $\mu_{2}$ Lagrange-szorzók értéke 0, ugyanakkor $\gamma_{1}$ és $\gamma_{2}$ értéke pozitív, azaz az 5. ÁLLíTÁs áll fenn. Ekkor a komplementaritás miatt (12) és (13) egyenlőség teljesül, ezért a $\theta_{0}^{1}$ és $\theta_{0}^{2}$ értéke a szabályozói elöírás nélkül meghatározott optimumhoz képest emelkedik. Az elsőrendü feltételekből nem esnek ki a $\gamma_{1}$-et és $\gamma_{2}$-öt tartalmazó tagok, ugyanakkor eliminálhatjuk azokat. Ha az elsőrendű feltételek közül a $\theta_{b 1}^{1}$ szerinti deriválással kapott egyenletből fejezzük ki a $\gamma_{1}$-et, és behelyettesítjük a $\theta_{a 2}^{1}$ szerinti deriválással kapott egyenletbe, akkor

$\frac{-a_{2}-b_{1}\left[\left(\delta_{2} x_{22}\right) /\left(\delta_{1} x_{11}\right)\right]}{c_{0}^{1}}+\frac{-x_{22}+\left[\left(\delta_{2} x_{22}\right) /\left(\delta_{1} x_{11}\right)\right] x_{11}}{2 c_{11}^{1}}+\frac{x_{22}-\left[\left(\delta_{2} x_{22}\right) /\left(\delta_{1} x_{11}\right)\right] x_{11}}{2 c_{12}^{1}}=0$.

Ha a szabályozói paraméter a két eszközre azonos, azaz $\delta=\delta_{1}=\delta_{2}$, akkor

$\frac{-a_{2}-b_{1}\left(x_{22} / x_{11}\right)}{c_{0}^{1}}=0$,

alakítva:

$\frac{-a_{2}}{b_{1}}=\frac{x_{22}}{x_{11}}$.

Ha feltesszük a készletek szimmetriáját, azaz $\omega_{0}^{1}=\omega_{0}^{2}$ és $\omega_{11}^{1}=\omega_{12}^{2}$, akkor a fogyasztásokra teljesül, hogy $c_{0}^{1}=c_{0}^{2}, c_{11}^{1}=c_{12}^{2}$ és $c_{11}^{2}=c_{12}^{1}$. Ezt kihasználva a vételi és eladási árak megadhatóak az árrés függvényében: $a_{1}=t_{1} / 2, b_{1}=-t_{1} / 2, a_{2}=t_{2} / 2$ és $b_{2}=-t_{2} / 2$. $\mathrm{Az}$ árrések között a szabályozói elöírás nélküli esethez hasonló összefüggés adódik: $t_{2}=t_{1} \frac{x_{22}}{x_{11}}$ 
és kihasználhatjuk a

$$
\begin{aligned}
& c_{0}^{1}=\omega_{0}^{1}-\frac{t_{1} \theta_{0}^{1}}{x_{11} \delta}-\theta_{0}^{1} \\
& c_{11}^{1}=\omega_{11}^{1}-\theta_{0}^{1} \frac{2}{\delta}+\theta_{0}^{1} \\
& c_{12}^{1}=\theta_{0}^{1} \frac{2}{\delta}+\theta_{0}^{1}
\end{aligned}
$$

költségvetési korlátokat, ezért az elsőrendű feltételek a következő egyenletre redukálódnak:

$$
\frac{\frac{-t_{1}}{2}-\delta \frac{1}{2} x_{11}}{\omega_{0}^{1}-\frac{t_{1} \theta_{0}^{1}}{x_{11} \delta}-\theta_{0}^{1}}+\frac{-x_{11}+\delta \frac{1}{2} x_{11}}{2\left(\omega_{11}^{1}-\theta_{0}^{1} \frac{2}{\delta}+\theta_{0}^{1}\right)}+\frac{x_{11}+\delta \frac{1}{2} x_{11}}{2\left(\theta_{0}^{1} \frac{2}{\delta}+\theta_{0}^{1}\right)}=0 .
$$

Az egyenletből kifejezhetjük $\theta_{0}^{1}$ értékét. Ha az árjegyző határozza meg a számára optimális árrést, akkor

$$
\max _{t_{1}, t_{2}} t_{1} \theta_{b 1}^{1}+t_{2} \theta_{a 2}^{1}=\max _{t_{1}} \frac{t_{1}}{x_{11}}\left(\theta_{b 1}^{1} x_{11}+\theta_{a 2}^{1} x_{22}\right)=\max _{t_{1}} \frac{t_{1}}{x_{11}} \frac{2 \theta_{0}^{1}}{\delta},
$$

feltéve, hogy a

$$
\frac{\frac{-t_{1}}{2}-\delta \frac{1}{2} x_{11}}{\omega_{0}^{1}-\frac{t_{1} \theta_{0}^{1}}{x_{11} \delta}-\theta_{0}^{1}}+\frac{-x_{11}+\delta \frac{1}{2} x_{11}}{2\left(\omega_{11}^{1}-\theta_{0}^{1} \frac{2}{\delta}+\theta_{0}^{1}\right)}+\frac{x_{11}+\delta \frac{1}{2} x_{11}}{2\left(\theta_{0}^{1} \frac{2}{\delta}+\theta_{0}^{1}\right)}=0
$$

feladatot oldja meg. A probléma alapján az árrés elszáll, így az árjegyző azt a legmagasabb árrést határozza meg, amely mellett a szabályozói előírás még nem válik redundánssá. A modellben lényegében a szabályozási paraméter értéke korlátozza az elszálló árrést. Megfigyelésünk összecseng Castellano-Cerqueti [2011] eredményével, amely szerint az árrésnek van egy optimális felső korlátja, amelyet a gazdasági körülményeknek megfelelöen az adott tőzsdének kellene szabályoznia. A kétszereplős speciális eset eredménye megerősíti az 1. SEJTÉsKÉNT megfogalmazott általános állítást. A szabályozói elöírás bevezetése az egyensúlyi árrés emelkedéséhez vezet. Az eredményt az 1. PÉLDA folytatásával illusztrálhatjuk.

2. PÉLDA • Vizsgáljuk az 1. PÉLDÁT szabályozói elöírás bevezetése esetén. Megfigyelhetö, hogy adott paraméterü $(\delta=0,4)$ szabályozási elöírás mellett az árjegyzö profitja folyamatosan emelkedik, ahogy egyre magasabb az árrés szintje. Ugyanakkor az elszálló árrést a redundánssá váló szabályozási elöírás korlátozza, így míg szabályozói elöirás nélkül az 1. PÉLDÁBAN 4,58 lett az optimális árrés értéke, 0,4 paraméterü szabályozói elöírás bevezetése esetén az egyensúlyi árrés 5,84. Ha az árrés tovább emelkedik, akkor a piaci szereplök szabályozói elöírás nélkül meghatározott egyensúlyi portfóliója is teljesíti a szabályozói elöírást, így azt választják. 


\section{3. táblázat}

Eredmények endogén árrés $(\delta)$ esetén 0,4 paraméterü szabályozói elöírás mellett

\begin{tabular}{lcccc}
\hline$t_{1}=t_{2}$ & $\theta_{0}^{1}$ & $\Theta$ & $u^{1}=u^{2}$ & $\Pi$ \\
\hline 0 & 1,8 & 9,0 & 4,6 & 0 \\
1 & 1,5 & 7,4 & 4,5 & 1,5 \\
2 & 1,3 & 6,3 & 4,4 & 2,5 \\
3 & 1,1 & 5,3 & 4,3 & 3,2 \\
4 & 0,9 & 4,6 & 4,2 & 3,7 \\
4,58 & 0,86 & 4,3 & 4,19 & 3,95 \\
5 & 0,82 & 4,1 & 4,17 & 4,10 \\
5,8 & 0,75 & 3,7 & 4,13 & 4,37 \\
\hline
\end{tabular}

\section{Összefoglalás}

A tanulmányban felírt általános keretrendszer lehetővé teszi a tranzakciós költségként bevezetett árrés és a szabályozói elöírás következtében megváltozó optimális döntések vizsgálatát.

A piaci szereplők kereskedésének célja a jövőbeli kifizetés bizonytalanságából fakadó kockázat mérséklése, a fogyasztás simítása és hasznosságuk maximalizálása. A levezetett speciális esetben közvetlen kereskedés $\left(t_{1}=t_{2}=0\right)$ során tökéletes kockázatmegosztás valósul meg. Az árrés emelkedésének hatására a piaci szereplők kereskedett portfóliójának jövőbeli kifizetése fokozatosan csökken, míg egy szint fölött a szereplők már nem kereskednek egymással, így a diverzifikáció meghiúsul. Ha az árrés szintjéröl profitmaximalizáló árjegyző dönt, akkor egyensúlyban a piaci szereplők kereskednek egymással, a jövőbeli világállapotokban realizált kifizetések közötti különbség csökken.

A gyakorlatban alkalmazott szabályozói lépések célja sok esetben a kockázatvállalás visszafogása. Ennek megfelelően a modellben várható veszteség (Expected Shortfall) függvényeként definiált szabályozói előírást vezetünk be. A $\delta$ paraméter határozza meg, hogy a tőkekövetelmény a várható veszteség mekkora hányada legyen. Egyértelmü, hogy mivel szabályozás esetén egy új korláttal bővül a piaci szereplők feltételes szélsőérték-feladata, az optimalizáló szereplők helyzete nem javulhat. Amíg a szabályozói előírás redundáns, az egyensúly nem változik. Az exogén árrés növelésekor szigorúbb (magasabb $\delta$ melletti) szabályozói előírás is redundáns marad. Ha a szabályozói előírás miatt új egyensúly alakul ki, akkor a kereskedés és a kockázatmegosztás visszaesik, a piaci szereplők hasznossága alacsonyabb.

A szabályozói elöírás bevezetése az optimalizáló árjegyző problémáját is megváltoztatja. Ha adott szabályozói paraméter mellett a szabályozói elöírás köt, akkor az árjegyző egészen addig emeli az árrést, amíg a szabályozói elöírás redundáns nem lesz. Ebben az esetben az eszközök árrése a szabályozói elöírás bevezetésének hatására 
növekszik, így a piaci likviditás csökken. A $\delta$ szabályozói paraméter emelkedése mellett az árjegyzö optimális árrése emelkedik. Minél szigorúbb tehát a bevezetett szabályozói elörás, annál jobban csökken a piacon a likviditás. A modell felhívja a figyelmet arra, hogy a megfelelő szabályozási mechanizmus kiválasztásakor a szabályozás likviditásra gyakorolt hatását is célszerü figyelembe venni.

\section{Hivatkozások}

ACERBI, C.-SCANDOLO, G. [2008]: Liquidity risk theory and coherent measures of risk. Quantitative Finance, Vol. 8. No. 7. 681-692. o. http://dx.doi.org/10.1080/14697680802373975.

Aminud, Y.-Mendelson, H.-Wood, R. [1990]: Liquidity and the 1987 Stock Market Crash. Journal of Portfolio Management, Vol. 16. No. 3. 65-69. o. https://doi.org/10.3905/ jpm.1990.409268.

BCBS [2013]: Basel III: The Liquidity Coverage Ratio and liquidity risk monitoring tools. Basel Committee on Banking Supervision, Bank for International Settlements, január.

Begenau, J. [2019]: Capital Requirements, Risk Choice, and Liquidity Provision in a BusinessCycle Model. Journal of Financial Economics, Vol. 136. No. 2. 355-378. o. https://doi. org/10.1016/j.jfineco.2019.10.004.

Bigio, S. [2015]: Endogenous Liquidity and the Business Cycle. American Economic Review, Vol. 105. No. 6. 1883-1927. o. https://doi.org/10.1257/aer.20110035.

Brounen, D.-Koedijk, K. G.-Pownall, R. A. J. [2016]: Household financial planning and savings behavior. Journal of International Money and Finance, Vol. 69. No. 12. 95-107. o. https://doi.org/10.1016/j.jimonfin.2016.06.011.

Brunnermeier, M. K.-Pedersen, L. H. [2008]: Market Liquidity and Funding Liquidity. Review of Financial Studies, Vol. 22. No. 6. 2201-2238. o. https://doi.org/10.1093/rfs/hhn098.

Campbell, J. Y. [2016]: Restoring Rational Choice: The Challenge of Consumer Financial Regulation. American Economic Review, Vol. 106. No. 5. 1-30. o. https://doi.org/10.1257/ aer.p20161127.

Castellano, R.-Cerqueti, R. [2011]: The optimal bid/ask spread in a Specialist System. Economic Modelling, Vol. 28. No. 5. 2247-2253. o. https://doi.org/10.1016/j.econmod.2011.06.019.

CsóKa PÉTer [2017]: Fair Risk Allocation in Illiquid Markets. Finance Research Letters, Vol. 21. 228-234. o. https://doi.org/10.1016/j.frl.2016.11.007.

CsóKa PÉTER-Herings, P. J.-J. [2014]: Risk Allocation under Liquidity Constraints. Journal of Banking and Finance, Vol. 49. 1-9. o. https://doi.org/10.1016/j.jbankfin.2014.08.017.

CsóKa Péter-Herings, P. J.-J.-Kóczy Á. László [2007]: Coherent Measures of Risk from a General Equilibrium Perspective. Journal of Banking and Finance, Vol. 31. No. 8. 2517-2534. o. https://doi.org/10.1016/j.jbankfin.2006.10.026.

CsóKa Péter-Herings, P. J.-J.-Kóczy Á. László [2009]: Stable allocations of risk. Games and Economic Behavior, Vol. 67. No. 1. 266-276. o. https://doi.org/10.1016/j.geb.2008.11.001.

De Nicolò, G.-Gamba, A.-Lucchetta, M. [2014]: Microprudential Regulation in a Dynamic Model of Banking. The Review of Financial Studies, Vol. 27. No. 7. 2097-2138. o. https://doi.org/10.1093/rfs/hhu022.

Eisfeldt, A. L. [2004]: Endogenous Liquidity in Asset Markets. Journal of Finance, Vol. 59. No. 1. 1-30. o. https://doi.org/10.1111/j.1540-6261.2004.00625.x.

Erb Tamás-Havran Dániel [2015]: Mit veszítünk a piaci súrlódásokkal? A pénzügyi piacok mikrostruktúrája. Közgazdasági Szemle, 62. évf. 3. sz. 229-262. o. 
Gromb, D.-VAyanos, D. [2010]: A model of financial market liquidity based on intermediary capital. Journal of the European Economic Association, Vol. 8. No. 2/3. 456-466. o. https:// doi.org/10.1111/j.1542-4774.2010.tb00516.x.

HaVran DÁNIEL-SzưCs BALÁzs ÁRPÁD [2016]: Árjegyzői viselkedés belső kockázatmegosztás mellett. Szigma, 47. évf. 1-2. sz 1-30. o.

Herings, P. J.-J.-Zhou, Y. [2019]: Competitive Equilibria in Matching Models with Financial Constraints. GSBE Research Memorandum, 19/007. Maastricht University, Maastricht, 1-39. o. https://doi.org/10.2139/ssrn.3373744.

IOSC [2018]: Recommendations for Liquidity Risk Management for Collective Investment Schemes. International Organization of Securities Commissions, FR01/2018. február.

IOSC [2019a]: Liquidity in Corporate Bond Markets Under Stressed Condition. International Organization of Securities Commissions, FR10/2019. június.

IOSC [2019b]: Sustainable finance in emerging markets and the role of securities regulators. International Organization of Securities Commissions, CR01/2019. február.

Király Júlia-Nagy Márton-Szabó E. Viktor [2008]: Egy különleges eseménysorozat elemzése - a másodrendü jelzáloghitel-piaci válság és (hazai) következményei. Közgazdasági Szemle, 55. évf. 7-8. sz. 573-621. o.

Kiyotaki, N.-Moore, J. [2019]: Liquidity, Business Cycles, and Monetary Policy. Journal of Political Economy, Vol. 127. No. 6. 2926-2966. o. https://doi.org/10.1086/701891.

KőHEGy GerGELY-STÉPÁN GÁBOR [2003]: A versenyzői gazdaság stabilitása késleltetett áralkalmazkodás mellett. Közgazdasági Szemle, 50. évf. 2. sz. 112-135. o.

LÁNG PÉTER [2017]: A model of bank behaviour for the assessment of the potential balance sheet impact of the NSFR liquidity requirement. MNB Working Papers, No. 3. https://www. mnb.hu/letoltes/mnb-wp-2017-3-final-1.pdf.

LeRoy, S. F.-Werner, J. [2001]: Principles of Financial Economics. Cambridge University Press, https://doi.org/10.1017/cbo9781139162272.

Mitchell, M.-Pedersen, L. H.-Pulvino, T. [2007]: Slow Moving Capital. American Economic Review, Vol. 97. No. 2. 215-220. o. https://doi.org/10.1257/aer.97.2.215.

NAFfa, H.-FAIN, M. [2019]: Do ESG factors matter in emerging markets? Megjelent: Dömötör Barbara-Keresztúri Judit Lilla (szerk.): PRMIA Hungary Chapter Research Conference, 2019. Conference proceedings, Budapest, Corvinus University of Budapest, 26-34. o.

Sommer, K.-Sullivan, P. [2018]: Implications of US Tax Policy for House Prices, Rents, and Homeownership. American Economic Review, Vol. 108. No. 2. 241-274. o. https://doi. org/10.1257/aer.20141751.

Stolper, O. [2018]: It takes two to Tango: Households' response to financial advice and the role of financial literacy. Journal of Banking \& Finance, Vol. 92. No. 7. 295-310. o. https:// doi.org/10.1016/j.jbankfin.2017.04.014.

ZALAI ERNő [1998]: Általános egyensúlyi modellek alkalmazása gazdaságpolitikai elemzésekre. Közgazdasági Szemle, 45. évf. 12. sz. 1065-1081. o. 